\title{
A review of the genus Trichopalpus Rondani, 1856 (Diptera: Scathophagidae) of Russia
}

\section{Обзор видов рода Trichopalpus Rondani, 1856 (Diptera: Scathophagidae) фауны России}

\author{
A.L. Ozerov \\ A. $\Lambda$. Озеров \\ Zoological Museum, Lomonosov Moscow State University, Bol'shaya Nikitskaya 2, Moscow 125009, Russia. E-mail: \\ ozerov2455@rambler.ru \\ Зоологический музей, Московский государственный университет им. М.В. Ломоносова, Большая Никитская ул., 2, Москва \\ 125009 , Россия.
} key.

KEY WORDS: Diptera, Scathophagidae, Trichopalpus, Russia, review, new synonyms, new combination,

КЛЮЧЕВЫЕ СЛОВА: Diptera, Scathophagidae, Trichopalpus, Россия, обзор, новые синонимы, новая комбинация, определительная таблица.

ABSTRACT. Flies of the genus Trichopalpus Rondani, 1856 of Russia, which includes 6 species, are reviewed. Generic and species descriptions and keys for determination of species are given, and data on distributions are summarized. Two new synonyms are proposed: Chaetosa Coquillett, 1898 and Huckettia Vockeroth, 1995 with Trichopalpus Rondani, 1856. Microprosopa lacteipennis Ringdahl, 1920 is transferred to the genus Trichopalpus.

РЕЗЮМЕ. Дан обзор двукрылых рода Trichopalpus Rondani, 1856 фауны России, включающего 6 видов. Приведены диагноз рода, описания видов и ключ для определения видов рода Trichopalpus России, а также суммированы данные по распространению видов рода на территории России. Установлены 2 новых синонима: Chaetosa Coquillett, 1898 и Huckettia Vockeroth, 1995 синонимизированы с Trichopalpus Rondani, 1856. Вид Microprosopa lacteipennis Ringdahl, 1920 перемещен в род Trichopalpus.

\section{Introduction}

Trichopalpus Rondani, 1856 is a small genus within the family Scathophagidae. The species from the genera Chaetosa Coquillett, 1898 (1 species: punctipes (Meigen, 1826)) and Huckettia Vockeroth, 1995 (1 species: nearctica Vockeroth, 1995) are also included in the genus Trichopalpus.

Rondani [1856] when describing the genus Trichopalpus included only one species in this genus, Cordylura fraterna Meigen, 1826. He later [Rondani, 1866] included another one species in this genus, Cordylura punctipes Meigen, 1826. Becker [1894] as well as Rondani considered these both species in the genus Trichopalpus. Coquillett [1898] described the genus Chaetosa, transferred punctipes to this genus and designated this species as type-species of Chaetosa. In the same work, he described another genus, Opsiomyia, with the North American species O. palpalis Coquillett, 1898. Curran [1927] described the species nigribasis Curran, 1927 in the genus Trichopalpus. Ringdahl [1936] described the species pilirostris Ringdahl, 1936 in the genus Chaetosa. He also described the subgenus Paramicroprosopa with the species subarctica Ringdahl, 1936 in the genus Microprosopa. Hackman [1956] noted that the latter species is Microprosopa obscurella (Zetterstedt, 1846). Vockeroth [1965] synonymized the generic names Opsiomyia and Paramicroprosopa with Trichopalpus (as a result, the species obscurella moved to the genus Trichopalpus). He also synonymized the species name pilirostris with nigribasis. In 1995, Vockeroth validated generic name Huckettia and specific name nearctica, which he mentioned in the Manual of Nearctic Diptera, Vol.2 [Vockeroth, 1987].

It should be noted that the characters by which the species are divided into genera are unconvincing. So, Coquillett [1898] transferred punctipes to the genus Chaetosa on the basis of the presence of two (not one) setae in this species on the katepisternum. However, in punctipes katepisternal seta on anterior corner rarely (as a rule in males) absent. Vockeroth [1987] divides the North American species Trichopalpus and Chaeto$s a$ by the structure of postpedicel. Trichopalpus species have postpedicel with upper apical angle rounded, while in Chaetosa species, postpedicel with upper apical angle acute. At the same time, the type species of 
the genus Trichopalpus - T. fraternus has postpedicel with upper apical angle acute. Vockeroth [1987] indicated pollination on abdominal tergites as a character that distinguishes species of the genus Huckettia from Trichopalpus and Chaetosa. Actually, the best division into the genera Trichopalpus, Chaetosa, and Huckettia is based on differences in the structure of male abdominal sternites 4 and 5 and the male genitalia. All the abovementioned facts testify to the possibility that the genera Trichopalpus, Chaetosa and Huckettia might be better placed in one single genus Trichopalpus sensu lato, with three subgenera (Trichopalpus sensu stricto, Chaetosa and Huckettia).

The genus Trichopalpus consists of 8 species distributed in the Northern Hemisphere (2 Nearctic, 4 Holarctic, 2 Palaearctic) [Vockeroth, 1965, 1987, 1995; Gorodkov, 1986; Šifner, 2008]. The fauna of Russia includes 6 species [e.g., Gorodkov, 1970, 1986; Engelmark, 1999; Ovchinnikov, 2004, 2005, 2013; Humala, Polevoi, 2009; Ozerov, Barkalov, 2014; Ozerov, Krivosheina, 2014; Bagachanova et al., 2016], but no general work has been fulfilled.

Very little is known about the biology of Trichopalpus. Adults of $T$. punctipes are usually collected in grass along spring banks. The adult flies of $T$. fraternus are found on young stems of aquatic plants of the genus Sparganium (fam. Typhaceae). None of descriptions of larvae is published.

\section{Material and methods}

The specimens examined for this study are deposited in the Zoological Museum, Moscow State University, Russia (ZMUM) and Zoological Institute of Russian Academy of Sciences, St. Petersburg, Russia (ZISP). I also studied some material from the Institute of Systematics and Ecology of Animals, Russian Academy of Sciences, Siberian Branch, Novosibirsk, Russia (ISEA).

The majority of original Russian geographical names are given in transliteration, but names of some large geographical regions (e.g. Altai (=Altai Krai + Altai Republic), Krasnoyarsk Krai, Primorsky Krai, Sakha Republic (=Yakutia), Zabaykalsky Krai) follow these indicated in Google Earth software.

The terminology used in the generic diagnosis and species redescriptions follows McAlpine [1981], Cumming \& Wood [2009], and Stuckenberg [1999].

\section{Taxonomic part}

\section{Trichopalpus Rondani, 1856}

Trichopalpus Rondani, 1856: 100. Gender: masculine. Typespecies: Cordylura fraterna Meigen, by original designation.

Chaetosa Coquillett, 1898: 163. Gender: feminine. Type-species: Cordylura punctipes Meigen, by original designation - syn.n.

Opsiomyia Coquillett, 1898: 162. Gender: feminine. Typespecies: Opsiomyia palpalis Coquillett, by original designation.

Paramicroprosopa Ringdahl, 1936: 169 [as subgenus of $\mathrm{Mi}$ croprosopa Becker]. Gender: feminine. Type-species: Micropro- sopa subarctica Ringdahl, by original designation [=Cordylura obscurella Zetterstedt].

Huckettia Vockeroth, 1987: 1095. Nomen nudum.

Huckettia Vockeroth, 1995: 733. Gender: feminine. Type-species: Huckettia nearctica Vockeroth, by original designation syn.n.

Tricopalpus, error. (e.g., Rondani, 1856: 225; Becker, 1894:157; Curran, 1927: 255)

Trichopalpus species are slender, small flies (3-6 $\mathrm{mm}$ in body length) (Figs 1, 2); head rounded in profile; arista bare; palpus elongate, distinctly spatulate, without strong apical/subapical seta; proepisternum covered with hairs at middle part; anepisternum covered with setulae along dorsal margin and in posterior part only (Fig. 3); anepimeron bare; katepisternum with one strong seta in posterodorsal corner, in T.punctipes additionally with one moderate or small seta in upper anterior corner; postmetacoxal bridge absent; scutellum with a pair of strong apical and a pair of strong basal setae; wing clear or slightly darkened; $\mathrm{R}_{1}$ bare dorsally; male sternite 5 symmetrical (Figs 13-18); surstyli simple, symmerical (Figs 25-30). Ovipositor short and compact, with proctiger shifted dorsally. Tergites 7 and 8 each divided dorsally into two sclerites (Fig. 4). Sternite 7 large (Fig. 6). Sternite 8 represented by two compressed sclerites narrowed distally (Fig. 4). 1826)

Trichopalpus (Trichopalpus) fraternus (Meigen, Figs 1, 3-7, 13, 19, 25.

fraterna Meigen, 1826: 243 (Cordylura). Type-locality: not given.

Recorded in Russia from Belgorod and Leningrad Regions [Ovchinnikov, 2013] and from Far East by Ozerov \& Krivosheina [2014].

MATERIAL. Arkhangelsk Oblast: Arkhangelsk $\left(64.5461^{\circ} \mathrm{N}\right.$ $\left.40.5677^{\circ} \mathrm{E}\right)$, 4.VIII.2010, D. Gavryushin (1 q, ZMUM); Northern Dvina River $\left(64.5182^{\circ} \mathrm{N} 40.4215^{\circ} \mathrm{E}\right)$, 7.VIII.2010, D. Gavryushin (1 O, ZMUM); Solvychegovsk $\left(61.3421^{\circ} \mathrm{N} 46.9132^{\circ} \mathrm{E}\right)$, 17.VIII.2010, D. Gavryushin (1 $\sigma^{7}$, ZMUM); Astrakhan' Oblast: Baskunchak salt lake $\left(48.193^{\circ} \mathrm{N} 46.813^{\circ} \mathrm{E}\right), 2-4 . V .2010$, K. Tomkovich (1 $\sigma^{7}, 1$ \% $\left.\mathrm{ZMUM}\right)$; Ikryanoe $\left(46.112^{\circ} \mathrm{N} 47.767^{\circ} \mathrm{E}\right)$, 10.V.2010, K. Tomkovich (1 +, ZMUM); Chuvashia: Yadrin (55.88 $\left.{ }^{\circ} \mathrm{N} 42.29^{\circ} \mathrm{E}\right), 13$.VII.2009, N. Vikhrev (1 $\sigma^{7}, 4$ 우, ZMUM);

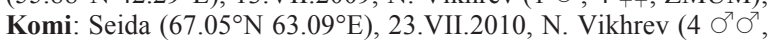
ZMUM); Khakassia: Prigorsk env. (53.92 $\left.{ }^{\circ} \mathrm{N} 91.41^{\circ} \mathrm{E}\right), 15$.VII.2017, N. Vikhrev (1 $\sigma^{7}$, ZMUM); Moscow and Moscow Oblast: Smolevo $\left(55.5788^{\circ} \mathrm{N} 38.6662^{\circ} \mathrm{E}\right), 25-31 . \mathrm{V} .2012$, K. Tomkovich $\left(1 \sigma^{7}\right.$, ZMUM); Andreevskoe (55.9763N $\left.35.5885^{\circ} \mathrm{E}\right), 10$. VIII.2007, A.L.

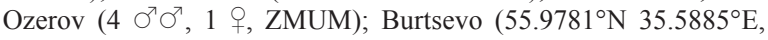
$55.9772^{\circ} \mathrm{N} 35.5874^{\circ} \mathrm{E}, 55.9766^{\circ} \mathrm{N} 35.5902^{\circ} \mathrm{E}, 55.9783^{\circ} \mathrm{N}$ $\left.35.5905^{\circ} \mathrm{E}, 55.9877^{\circ} \mathrm{N} 35.6008^{\circ} \mathrm{E}\right), 2 . I X .2007,28$.VII.2008, 4 and 8.VIII.2009, 10.VIII.20148, A.L. Ozerov (12 $\Im^{7} \Im^{7}, 6$ 우, ZMUM); Dedinovo $\left(55.0524^{\circ} \mathrm{N} 39.1234^{\circ} \mathrm{E}\right), 31$. VII.1984, B.M. Mamaev (1 $\sigma^{7}$, ZMUM); Dmitrov env. (56.3163ㅇ $\left.37.7258^{\circ} \mathrm{E}\right)$, 9.IX.2003, 14.VI. and 4-7.VII.2007, N. Vikhrev (8 $\sigma^{7} \sigma^{7}$, ZMUM); Izmaylovo $\left(55.8023^{\circ} \mathrm{N} 37.8440^{\circ} \mathrm{E}\right), 5 . \mathrm{VI} .1983,20 . \mathrm{VI} .2007$, A.L. Ozerov (7 $\sigma^{\top} \sigma^{\top}, 11$ 우, ZMUM); Naro-Fominsk $\left(55.3654^{\circ} \mathrm{N} 36.7437^{\circ} \mathrm{E}\right)$, 4.VIII.2010, D. Gavryushin (1 9 , ZMUM); Ozhigovo $\left(55.4533^{\circ} \mathrm{N}\right.$ $\left.36.8847^{\circ} \mathrm{E}\right), 6 . \mathrm{IX} .2007, \mathrm{D}$. Gavryushin (1 $\sigma^{\top}, \mathrm{ZMUM}^{\prime}$ ); Pushchino $\left(54.8361^{\circ} \mathrm{N} 37.6232^{\circ} \mathrm{E}\right), 3$.VII.1984, M. Krivosheina (1 9 , ZMUM); Skhodnya River $\left(55.9230^{\circ} \mathrm{N} 37.3487^{\circ} \mathrm{E}\right), 20 . \mathrm{VI} .2011$, A.L. Ozerov (2 $\sigma^{7} \sigma^{7}$, ZMUM); Yur'evo $\left(56.0057^{\circ} \mathrm{N} 35.5450^{\circ} \mathrm{E}, 56.0067^{\circ} \mathrm{N}\right.$ $\left.35.5460^{\circ} \mathrm{E}, 56.0066^{\circ} \mathrm{N} 35.5462^{\circ} \mathrm{E}\right), 2$ and 9.VIII.2007, 29.VII.2009, 

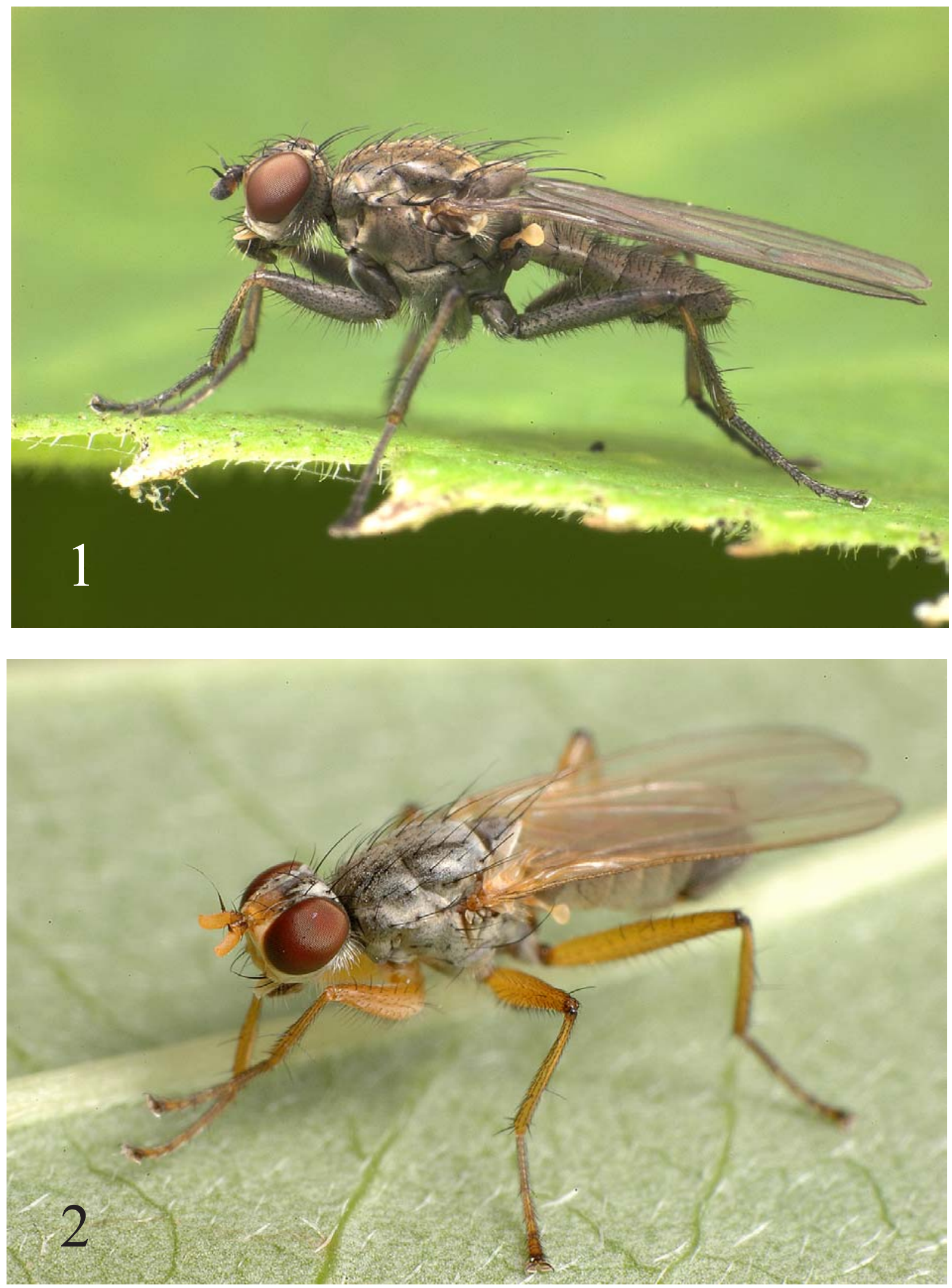

Figs 1-2. Male habitus of Trichopalpus fraternus (Meigen) (1) and T. punctipes (Meigen) (2). Photographs by D. Gavryushin. Рис. 1-2. Общий вид самца Trichopalpus fraternus (Meigen) (1) и T. punctipes (Meigen) (2). Фото Д. Гаврюшина. 

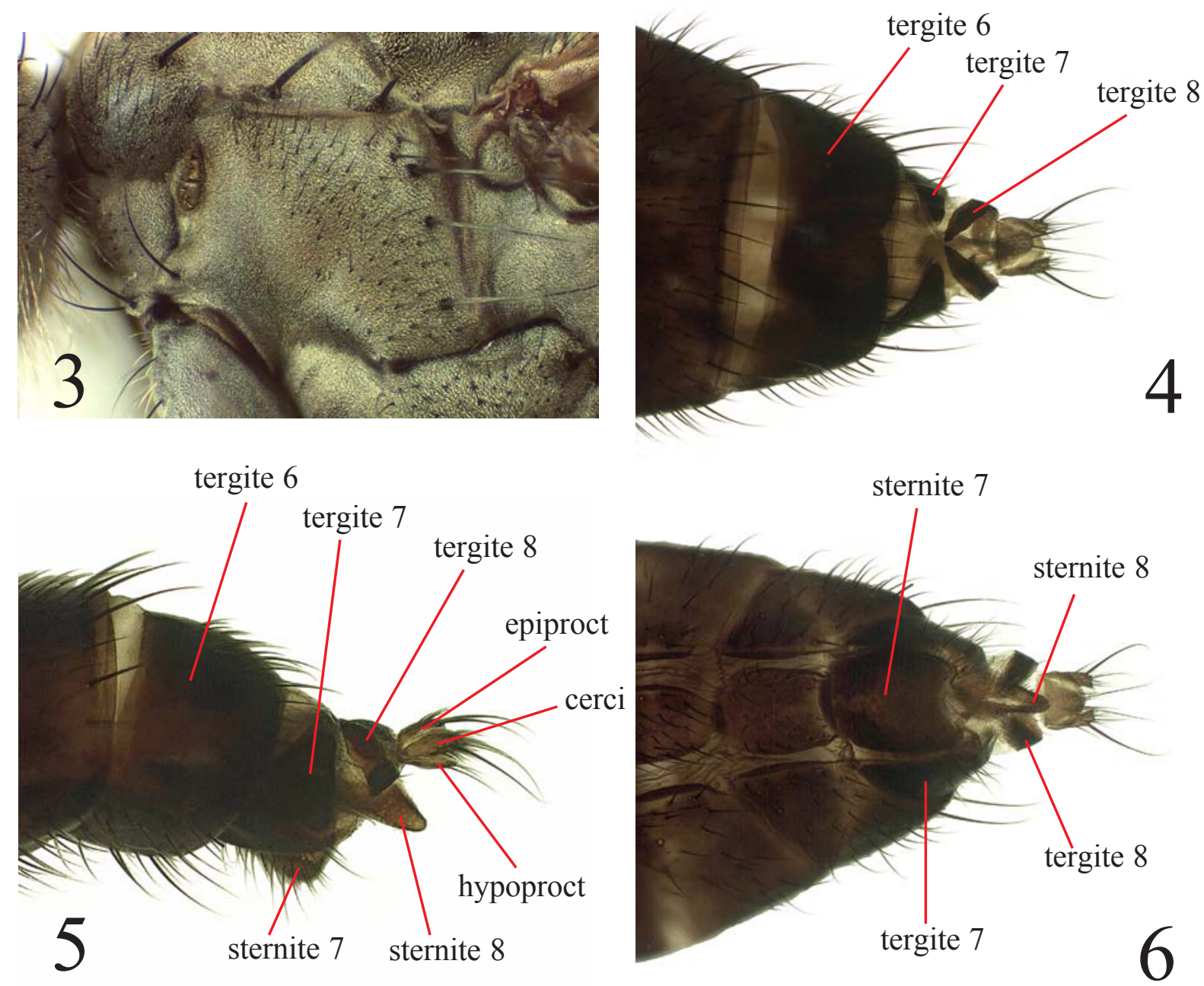

Figs 3-6. Trichopalpus fraternus (Meigen): 3 - anepisternum; 4 - end of female abdomen, dorsal view; 5 - same, lateral view; 6 same, ventral view. снизу.

Pис 3-6. Trichopalpus fraternus (Meigen): 3 - анэпистернум; 4 - конец брюшка самки, сверху; 5 - то же, сбоку; 6 - то же,

17.VII.2010, A.L. Ozerov (4 $0^{7} \sigma^{7}, 1$,, ZMUM); Nizhegorod Oblast: Dzerzhinsk $\left(56.21^{\circ} \mathrm{N} 43.62^{\circ} \mathrm{E}\right), 16$ and 17.VIII.2009, N. Vikhrev ( $10^{7}, 2$ 우, ZMUM); Omsk Oblast: Achairsky monastery $\left(54.6694^{\circ} \mathrm{N} 73.8194^{\circ} \mathrm{E}\right), 22 . \mathrm{VI} .2008$, O. Kosterin (1 $\mathrm{O}^{7}$, ZMUM); Primorsky Krai: Kamenushka $\left(43.6342^{\circ} \mathrm{N} 132.2220^{\circ} \mathrm{E}\right)$, 11.VII.1984, A. Shatalkin (1 ${ }^{7}$, ZMUM), same place, 8.VIII.1983, VII.1984, A.L. Ozerov (2 90, ZMUM); Khanka Lake $\left(45.06^{\circ} \mathrm{N}\right.$ 131.99²E), 15-19.VI.2014, N. Vikhrev (1 ㅇ, ZMUM); Ryazan Oblast: Kasimov env. $\left(54.94^{\circ} \mathrm{N} 41.34^{\circ} \mathrm{E}\right), 17-19 . \mathrm{VI} .2013, \mathrm{~N}$. Vikhrev (2 $\left.\mathrm{O}^{\top} \mathrm{O}^{\top}, \mathrm{ZMUM}\right)$; Zalesnoe $\left(54.969^{\circ} \mathrm{N} 41.327^{\circ} \mathrm{E}\right), 21-$ 26.VII.2013, N. Vikhrev (12 $\mathrm{O}^{7} \mathrm{O}^{7}, 8$ 우, ZMUM); Tver' Oblast: Derbovezh env. $\left(56.33^{\circ} \mathrm{N} 31.97^{\circ} \mathrm{E}\right), 21 . \mathrm{VI} .2012$, N. Vikhrev $(1$ \% ZMUM); Volgo Lake $\left(56.8766^{\circ} \mathrm{N} 33.2439^{\circ} \mathrm{E}\right), 1^{18}-19 . \mathrm{VIII} .2011$, A.L. Ozerov (3 $\sigma^{7} O^{7}, 2$ $9+$, ZMUM); Ul'yanovsk Oblast: Radishchevo $\left(55.836^{\circ} \mathrm{N} 48.367^{\circ} \mathrm{E}\right), 7-9 . V .2011, \mathrm{~K}$. Tomkovich $(1$, ZMUM).

DESCRIPTION. Male, female. Medium-sized flies (4.2-5.6 mm long).

Head. Frontal vitta blackish in upper part, only in lower third or quarter yellow reddish, matt; frontoorbital plate and ocellar triangle black, greyish dusted.
Face blackish, greyish dusted. Parafacial yellow. Gena usually yellow, rarely blackish in posterior half, greyish dusted. Postgena black, greyish dusted. Postcranium black, greyish dusted, covered with black setae in upper third and pale hairs in lower part. 3 orbitals, 2-4 frontals, 1 ocellar, 1 postocellar (very small), 1 inner vertical, 1 outer vertical; 2 pairs of vibrissae present. Antenna black, postedicel reddish inside at base. Postpedicel with slightly acute upper apical corner, about 2.0 times as long as wide. Arista black, basally thickened, bare. Clypeus and proboscis black. Palpus yellow.

Thorax black, greyish dusted. Acrostical hairs in two rows, dorsocentrals $3+3$, including short erect seta on anterior margin of scutum, intra-alars $1+2$, supraalars $1+2$, postpronotals 2 , notopleurals 2 , postalars 2 . Proepisternum covered with hairs anteriorly, with 2 setae near lower margin. Proepimeron with one seta. 

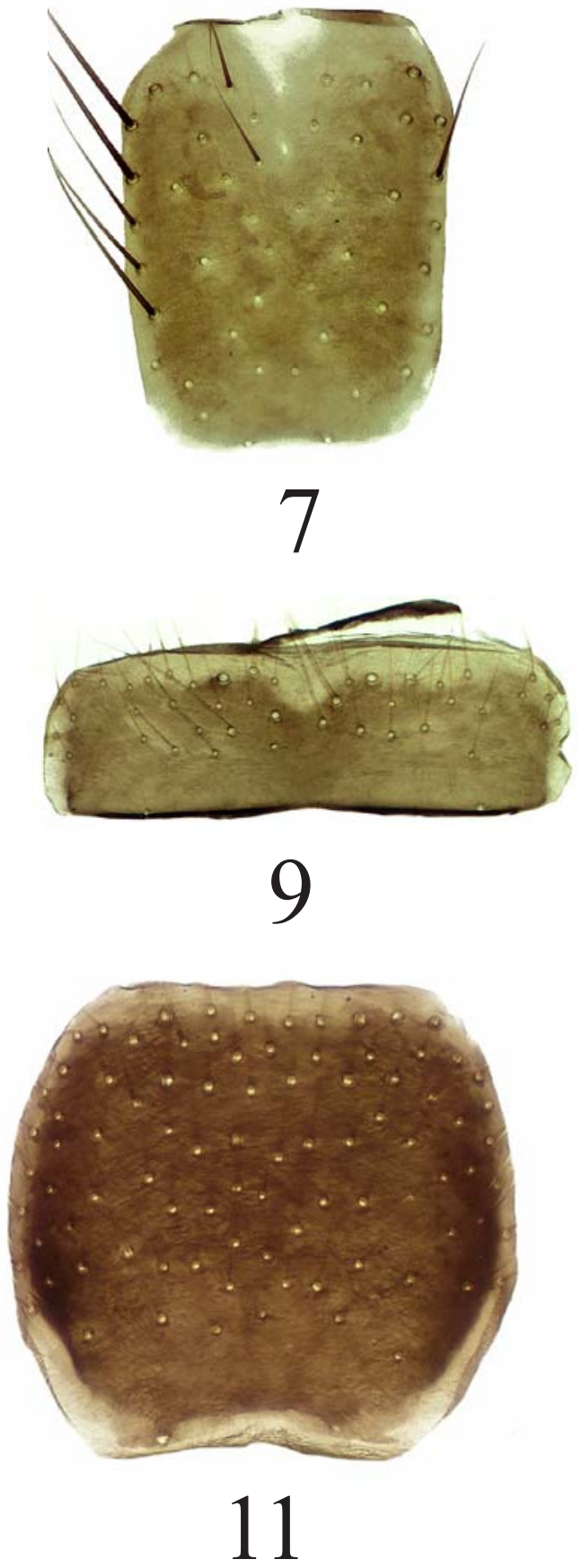

Figs 7-12. Male sternite 4 of Trichopalpus spp.: $7-$ T. fraternus (Meigen); $8-$ T. lacteipennis (Ringdahl); $9-$ T. nearcticus (Vockeroth); $10-$ T. nigribasis (Curran); $11-$ T. obscurellus (Zetterstedt); $12-$ T. punctipes (Meigen).

Рис 7-12. Стернит 4 самца видов Trichopalpus: $7-$ T. fraternus (Meigen); $8-$ T. lacteipennis (Ringdahl); $9-$ T. nearcticus (Vockeroth); $10-$ T. nigribasis (Curran); $11-$ T. obscurellus (Zetterstedt); $12-$ T. punctipes (Meigen).

Anepisternum covered with hairs in posterior half, with 3-4 setae along posterior margin. Katepisternum covered with hairs in posterior half and with 1 strong seta in upper posterior corner. Anepimeron bare. Scutellum black, greyish dusted, with a pair of basal scutellar and a pair of apical scutellar setae.

Legs. Coxae and trochanters of all legs black. Usually: fore femur black, but yellow in apical quarter or
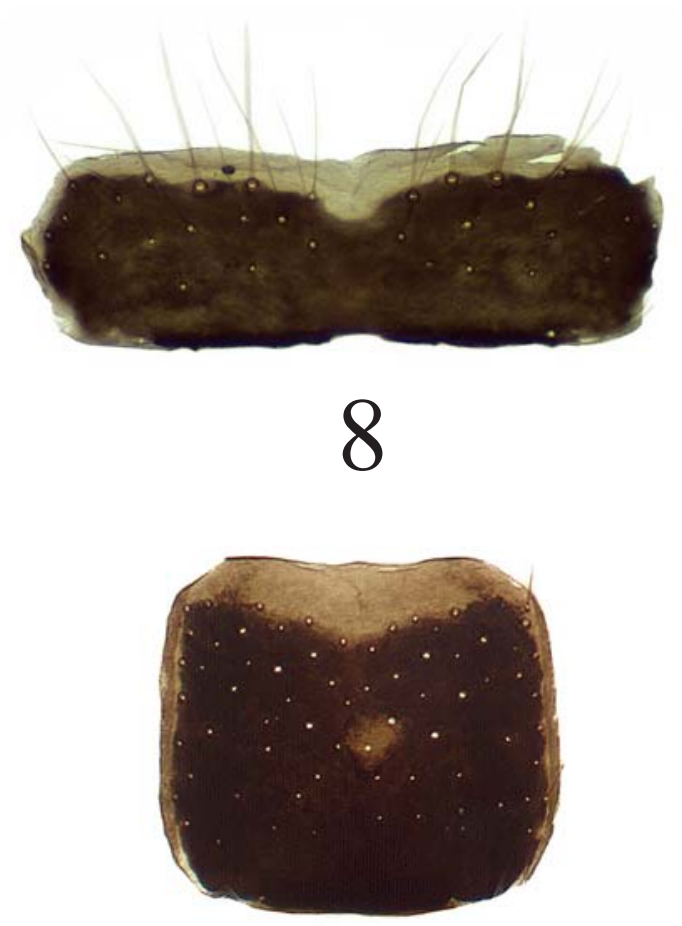

10
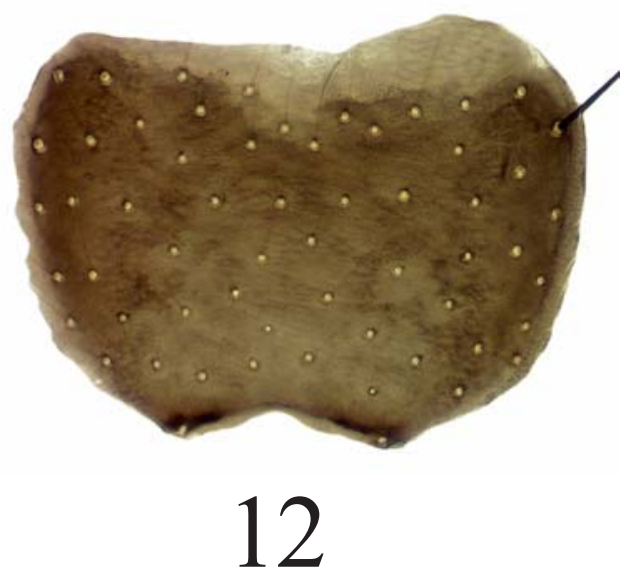

third, mid and hind femora black in central part and yellow basally and apically; tibiae and tarsi of all legs yellow. Sometimes mid and hind femora and tibiae blackish almost completely. Fore femur with a row of posterodorsal setae, and covered with more or less long hairs posteroventrally. Fore tibia with 1 dorsal and 1 posterior/posteroventral setae in lower half, with 1 preapical dorsal/posterodorsal seta and 1 apical poste- 
rior seta. Mid femur with a row of anterior setae, with 1 preapical anterior/anterodorsal and 1 preapical posterodorsal setae. Mid tibia with 1 anterodorsal, $0-1$ posterodorsal setae near middle, also with a ring of apicals in both sexes, additionally with 1 ventral seta near middle in female. Hind femur with a row of anterodorsal setae and with 4-5 anteroventral setae in apical third. Hind tibia with 2 anterodorsal, 2 posterodorsal, 0-1 anteroventral, 1 preapical dorsal, 1 preapical anterodorsal and 1 apical anteroventral setae.

Wing clear or slightly darkened; veins brown. $\mathrm{R}_{1}$ bare dorsally. Calypters, margins of calypters, and halteres whitish or yellowish.

Abdomen black, greyish dusted; syntergite $1+2$ and tergites 3-6 with a row of marginal setae. Male sternite 4 about 1.5 times as long as wide (Fig. 7). Male sternite 5 with lobes narrowed apically and curved internally (Fig. 13). Epandrium and surstyli as in Figs 19, 25. Ovipositor as in Figs. 4-6.

DISTRIBUTION. Russia: Arkhangelsk Oblast, Astrakhan Oblast, Belgorod Oblast, Chuvashia, Komi, Khakassia, Leningrad Oblast, Moscow Oblast, Nizhegorod Oblast, Omsk Oblast, Primorsky Krai, Ryazan’ Oblast, Tver' Oblast, Ul'yanovsk Oblast. — Europe (widespread).

Trichopalpus (Huckettia) lacteipennis (Ringdahl, 1920), comb.n.

Figs 8, 14, 20, 26.

lacteipennis Ringdahl, 1920: 38 (Microprosopa). Type-locality: "in Lappland auf dem Gebirge Tjuonjatjakko ca 1000 Meter..."

Noted by Gorodkov [1970] for European part of Russia from Kola Peninsula.

MATERIAL. Arkhangelsk Oblast: the lower reaches of the Pechora River $\left(68.3348^{\circ} \mathrm{N} 53.3046^{\circ} \mathrm{E}\right), 11$. VII.2008, A.L. Ozerov (2 $\sigma^{7} \sigma^{7}$, ZMUM). Krasnoyarsk Krai: Ust'-Tareya $\left(73.2527^{\circ} \mathrm{N}\right.$ 90.5962 $\left.{ }^{\circ} \mathrm{E}\right), 24$. VII.1967, Gorodkov (2 $\sigma^{7} \sigma^{7}$, ZMUM, ZISP).

ADDITIONAL MATERIAL. Sweden: TLpm: Abisko, Birch Forest $1 \mathrm{~km}$ NW of NatVetStn, 24.VI.1997 A.C. Pont (1 $\sigma^{7}$, ZMUM)

DESCRIPTION. Male. Medium-sized flies (3.0$4.1 \mathrm{~mm}$ long).

Head. Frontal vitta blackish in upper part and yellow in lower half, third or quarter only; matt. Frontoorbital plate black, greyish dusted. Face, parafacial and gena yellow. Postgena black, greyish dusted. Postcranium black, greyish dusted, covered with black setae in upper third and pale hairs in lower part. 3 orbitals, 2-3 frontals, 1 ocellar, 1 postocellar (short), 1 inner vertical, 1 outer vertical; 2 pairs of vibrissae present. Antenna black, only postpedicel usually yellow inside basally. Postpedicel with more or less rounded upper apical corner, 1.5-2.0 times as long as wide. Arista black, basally thickened, bare. Clypeus and proboscis black. Palpus yellow.

Thorax black, greyish dusted, but katepisternum and meron each with shining spot. Acrostical hairs in two rows, dorsocentrals $(3-4)+(3-4)$, including short erect seta on anterior margin of scutum, intra-alars $1+2$ (usually small), supra-alars $1+2$, postpronotals 2 , notopleurals 2, postalars 2. Proepisternum covered with hairs anteriorly, with 1-2 setae near lower margin. Proepimeron with one seta. Anepisternum covered with hairs in posterior half, with 3-4 setae along posterior margin. Katepisternum covered with hairs in posterior half, with 1 strong seta in upper posterior corner. Anepimeron bare. Scutellum black, greyish dusted, with a pair of basal scutellar and a pair of apical scutellar setae.

Legs black in ground color, greyish dusted; tibiae from black to yellowish (usually brownish). Fore femur with a row of posterodorsal setae. Fore tibia curved, with 1 preapical dorsal and 1 apical posterior setae. Mid femur with a row of anterior setae, with 1 preapical posterior and 1 preapical posterodorsal setae. Mid tibia with 1 anterodorsal, 1 posterodorsal and a ring of apical setae. Hind femur with a row of anterodorsal setae and several anteroventral setae in apical half. Hind tibia with 2 anterodorsal, 2 posterodorsal, 1 preapical dorsal, 1 apical/preapical anterodorsal and 1 apical anteroventral setae.

Wing tinged with brownish; veins brown. $\mathrm{R}_{1}$ bare dorsally. Crossvein $\mathrm{r}-\mathrm{m}$ darkened. Calypters, margins of calypters, and halteres yellowish or brownish.

Abdomen black, greyish dusted dorsally, shining laterally. Male sternite 4 rectangular, about 0.3 times as long as wide (Fig. 8). Male sternite 5 with broad triangular lobes (Fig. 14). Epandrium and surstyli as in Figs 20, 26.

NOTE. The species was described in the genus Microprosopa Becker, 1894 and to date has been in this genus [Nelson, Greve, 2002; Šifner, 2008; Kahanpää, Haarto, 2014]. T. lacteipennis is very similar to $T$. nearcticus both externally (see below) and in structure of male sternites 4 and 5 (compare Figs 8, 9, 14,15 ) and male surstyli (compare Figs 26, 27). Other differences are given in the key (see below).

DISTRIBUTION. Russia: Arkhangelsk Oblast, Krasnoyarsk Krai. — Europe (Scandinavia). 1995)

Trichopalpus (Huckettia) nearcticus (Vockeroth,

Figs 9, 15, 21, 27.

nearctica Vockeroth, 1987: 1095. (Huckettia). Nomen nudum. nearctica Vockeroth, 1995: 733 (Huckettia). Type-locality: Beaverhill Lake (664 4 'N, 104²0'W) (Canada).

Recorded in Russia from Siberia (Yakutia) [Engelmark, 1999] and Russian Far East (Chukotka) [Ozerov, Krivosheina, 2014].

ADDITIONAL MATERIAL. Canada: Beaverhill L., N.W.T. $62^{\circ} 44^{\prime}$ N. $104^{\circ} 20^{\prime}$ W. 29.VI.1966, G.E. Shewell (1 ○', 1 ㅇ, ZMUM); Nr. Beechey L., N.W.T. $65^{\circ} 14^{\prime}$ N. $106^{\circ} 50^{\prime}$ W. 18.VII.1966, G.E. Shewell (1 9 , ZMUM); Salmita Mines, $64^{\circ} 05^{\prime}$ N. $111^{\circ} 15^{\prime}$ W. N.W.T., 19.VII.1953, J.G. Chillcott (1 $\sigma^{7}$, ZMUM); Spence Bay N.W.T., 11.VII.1951, J.G. Chillcott (1 $\sigma^{7}$, ZMUM); Clyde, GaffinIs., N.W.T., 24.VII.1958, G.E. Shewell (1 O', ZMUM).

DESCRIPTION. Male, female. Medium-sized flies (3.2-5.1 mm long).

Head. Frontal vitta blackish in upper part and reddish yellow in lower half, third or only quarter; matt. Fronto-orbital plate black, greyish dusted. Face, parafacial and gena reddish yellow. Postgena black, greyish dusted. Postcranium black, greyish dusted, covered with 

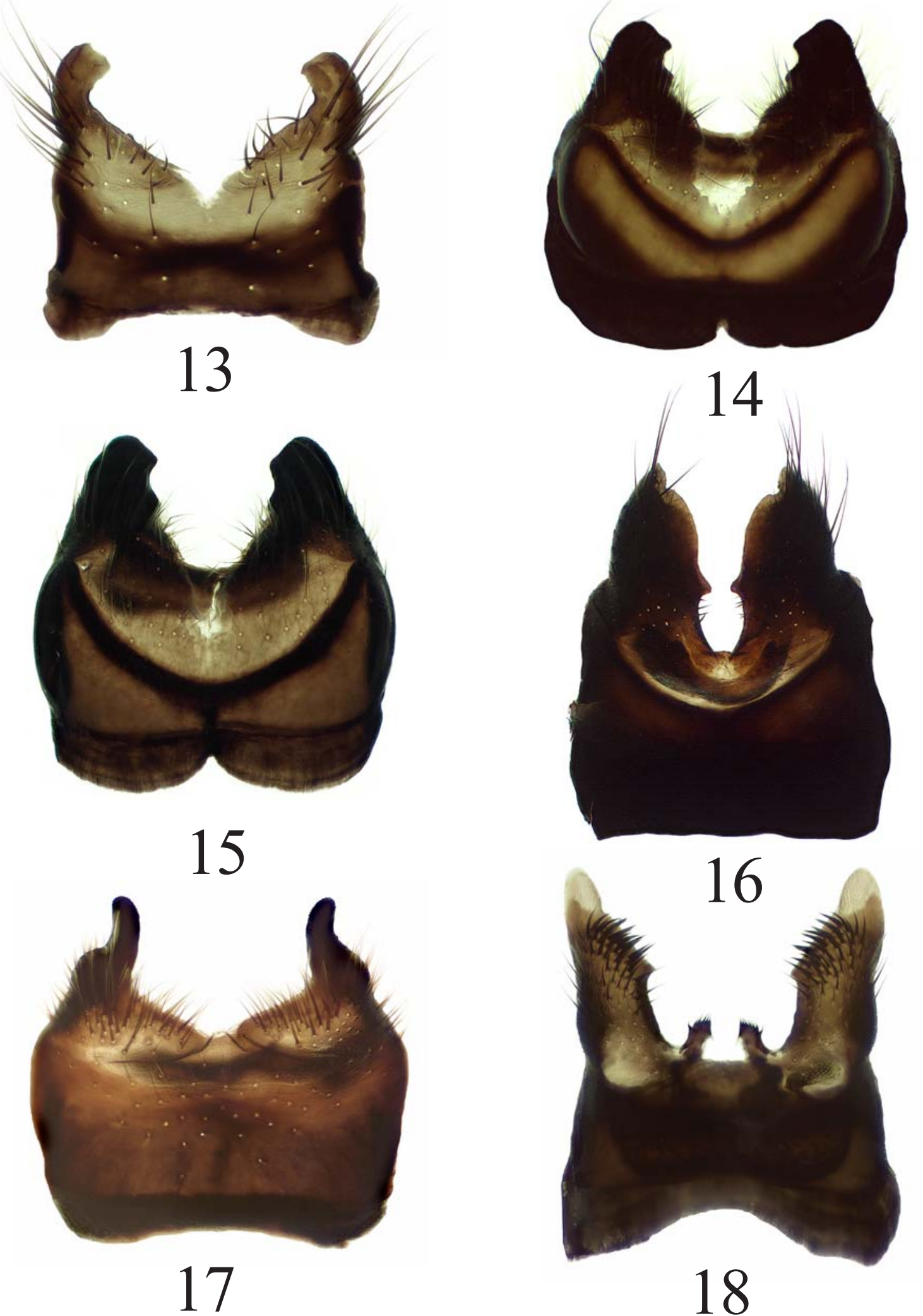

Figs 13-18. Male sternite 5 of Trichopalpus spp.: $13-T$. fraternus (Meigen); $14-T$. lacteipennis (Ringdahl); $15-T$. nearcticus (Vockeroth); $16-$ T. nigribasis (Curran); $17-$ T. obscurellus (Zetterstedt); $18-$ T. punctipes (Meigen).

Рис 13-18. Стернит 5 самца видов Trichopalpus: $13-$ T. fraternus (Meigen); $14-$ T. lacteipennis (Ringdahl); $15-$ T. nearcticus (Vockeroth); 16 - T. nigribasis (Curran); $17-$ T. obscurellus (Zetterstedt); $18-$ T. punctipes (Meigen). 

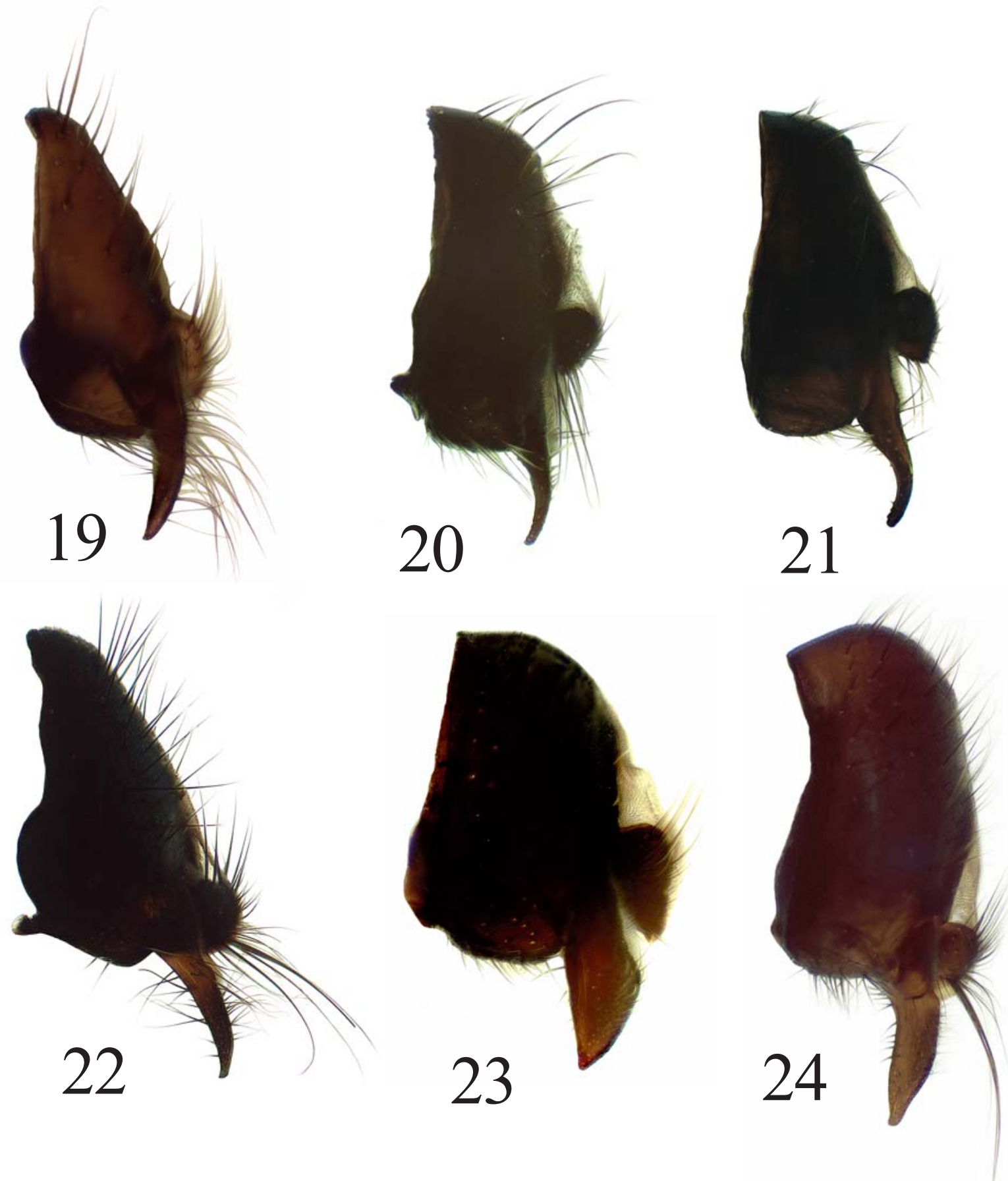

Figs 19-24. Epandrium, cerci and surstyli, lateral view of Trichopalpus spp.: $19-$ T. fraternus (Meigen); $20-T$. lacteipennis (Ringdahl); $21-$ T. nearcticus (Vockeroth); $22-$ T. nigribasis (Curran); $23-$ T. obscurellus (Zetterstedt); $24-$ T. punctipes (Meigen). Рис. 19-24. Эпандрий, церки и сурстили, вид сбоку видов Trichopalpus: $19-$ T. fraternus (Meigen); $20-T$. lacteipennis (Ringdahl); $21-$ T. nearcticus (Vockeroth); $22-$ T. nigribasis (Curran); $23-$ T. obscurellus (Zetterstedt); $24-$ T. punctipes (Meigen).

black setae in upper third and pale hairs in lower part. 3 orbitals, 2-3 frontals, 1 ocellar, 1 postocellar (short), 1 inner vertical, 1 outer vertical; 2 pairs of vibrissae present. Antenna black, only postpedicel usually yellow inside basally. Postpedicel with more or less rounded upper apical corner, 1.5-2.0 times as long as wide. Arista black, basally thickened, bare. Clypeus and proboscis black. Palpus yellow.
Thorax black, greyish dusted, but katepisternum and meron each with shining spot. Acrostical hairs in two rows, dorsocentrals (3-4)+3, including short erect seta on anterior margin of scutum (only prescutellar seta strong), intra-alars $1+2$ (usually very small), supra-alars $1+2$, postpronotals 2 , notopleurals 2 , postalars 2. Proepisternum covered with hairs anteriorly, with 1-2 setae near lower margin. Proepimeron with 
one seta. Anepisternum covered with hairs in posterior half, with 3-4 setae along posterior margin. Katepisternum covered with hairs in posterior half, with 1 strong seta in upper posterior corner. Anepimeron bare. Scutellum black, greyish dusted, with a pair of basal scutellar and a pair of apical scutellar setae.

Legs black in ground color, greyish dusted; tibiae from black to yellowish (usually black). Fore femur with a row of posterodorsal setae. Male fore tibia curved, with 1 strong posterior seta, with 1 preapical dorsal and 1 apical posterior setae. Female fore tibia more or less direct, with 1 posterior, 0-1 anterodorsal, 1 preapical dorsal and 1 apical posterior setae. Mid femur with a row of anterior setae (unclear in male), with 1 preapical posterior and 1 preapical posterodorsal setae. Mid tibia with 1 anterodorsal, 1 posterodorsal and a ring of apical setae. Hind femur with a row of anterodorsal setae and several anteroventral setae in apical half. Hind tibia with 2 anterodorsal, 2 posterodorsal, 1 preapical dorsal, 1 apical/preapical anterodorsal and 1 apical anteroventral setae.

Wing tinged with brownish; veins brown. $\mathrm{R}_{1}$ bare dorsally. Crossvein $\mathrm{r}-\mathrm{m}$ darkened. Calypters, margins of calypters, and halteres yellowish or brownish.

Abdomen black, greyish dusted dorsally, shining laterally. Male sternite 4 rectangular, about 0.3 times as long as wide (Fig. 9). Male sternite 5 with broad triangular lobes (Fig. 15). Epandrium and surstyli as in Figs 21, 27.

DISTRIBUTION. Russia: Yakutia [Engelmark, 1999] and Chukotka [Ozerov, Krivosheina, 2014]. North America.

Trichopalpus (Chaetosa) nigribasis (Curran, 1927) Figs 10, 16, 22, 28.

nigribasis Curran, 1927: 255 (Tricopalpus). Type-locality: "Banff", Alberta (Canada).

pilirostris Ringdahl, 1936: 178 (Chaetosa). Type-locality: "bei Tromsö im nördlichen Norwegen" (Norway).

Recorded in Russian Far East by Ozerov \& Krivosheina [2014].

MATERIAL. Amur Oblast: town Zeya $\left(53.7485^{\circ} \mathrm{N}\right.$ 127.2614 ${ }^{\circ}$ E), 11 and 18.VI.1978, A. Shatalkin (2 o+ , ZMUM); Arkhangelsk Oblast: Solvychegovsk $\left(61.3421^{\circ} \mathrm{N} 46.9132^{\circ} \mathrm{E}\right)$, 15.VIII.2010, D. Gavryushin (1 + , ZMUM).

DESCRIPTION. Male, female. Medium-sized flies (5.0-5.8 mm long).

Head. Frontal vitta black, only along lunula yellow, matt. Fronto-orbital plate black, greyish dusted. Face, parafacial and gena yellow. Postgena black, greyish dusted. Postcranium black, greyish dusted, covered with black setae in upper third and pale hairs in lower part. 3 orbitals, 3-5 frontals, 1 ocellar, 1 postocellar (very small), 1 inner vertical, 1 outer vertical; 2 pairs of vibrissae present. Antenna black. Postpedicel with acute upper apical corner, about 2.5 times as long as wide. Arista black, basally thickened, bare. Clypeus and proboscis black. Palpus yellow in apical part and black basally, sometimes blackish completely.

Thorax black, greyish dusted. Acrostical hairs in two rows, dorsocentrals $(3-4)+3$, including short erect seta on anterior margin of scutum, intra-alars $1+2$, supra-alars $1+2$, postpronotals 2 , notopleurals 2 , postalars 2. Proepisternum covered with hairs anteriorly, with 1-2 setae near lower margin. Proepimeron with one seta. Anepisternum covered with hairs in posterior half, with 3-4 setae along posterior margin. Katepisternum greyish dusted completely, covered with hairs in posterior half, with 1 strong seta in upper posterior corner. Anepimeron bare. Scutellum black, greyish dusted, with a pair of basal scutellar and a pair of apical scutellar setae.

Legs. Coxae and trochanters of all legs black. Femora and tibiae of all legs yellow. Tarsi of all legs from dark yellow to blackish. Fore femur with rows of posterodorsal (normal) and ventral (long and thin) setae. Fore tibia with 1 dorsal and 1 posterior/posteroventral setae in lower half, with 1 preapical dorsal/posterodorsal, 1 preapical anterodorsal and 1 apical posterior setae. Mid femur with a row of anterior setae, with 1 preapical anterior/anterodorsal and 1 preapical posterodorsal setae. Mid tibia with 1 anterodorsal, 1 posterodorsal and 1 ventral setae near middle, also with a ring of apicals. Hind femur with a row of anterodorsal setae and several anteroventral setae in apical half. Hind tibia with 2 anterodorsal, 2 posterodorsal, 1 anteroventral, 1 preapical dorsal, 1 apical/preapical anterodorsal and 1 apical anteroventral setae.

Wing brownish tinged; veins brownish. $\mathrm{R}_{1}$ bare dorsally. Calypters, margins of calypters, and halteres yellowish or brownish.

Abdomen black, greyish dusted; female syntergite $1+2$ and tergites 3-6 with a row of marginal setae. Male sternite 4 square (Fig. 10). Male sternite 5 with broad rounded lobes, each carrying small tubercle at the middle of internal side and at apex (Fig. 16). Epandrium and surstyli as in Figs 22, 28.

DISTRIBUTION. Russia: Amur Oblast, Arkhangelsk Oblast. — Europe (Scandinavia), North America.

Trichopalpus (Trichopalpus) obscurellus (Zetterstedt, 1846)

Figs 11, 17, 23, 29.

obscurella Zetterstedt, 1846: 2043 (Cordylura). Type-locality: "Lapponia Lulensi ad Qvickjock ... alpibus Dalecarlicis ab Eodem" (Sweden).

subarctica Ringdahl, 1936: 177 (Microprosopa). Type-localities: "Ufer von Torneträsk im nördlichen Lappland...bei Åresjön in Jämtland" (Sweden).

Recorded in Russian Far East from Chukotka by Ozerov \& Krivosheina [2014].

MATERIAL. Chukotka: Meynypil'gyno env. $\left(62.6283^{\circ} \mathrm{N}\right.$

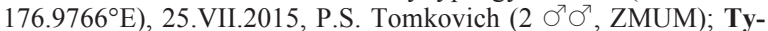
umen' Oblast: the upper reaches of the Pura River (ca. $66.3202^{\circ} \mathrm{N}$ $\left.77.989^{\circ} \mathrm{E}\right), 10 \mathrm{~km} \mathrm{NW}$ of Barasmu Lake, 21-24.VII.1967, Gorodkov $\left(1 \sigma^{7}\right.$, ZISP).

ADDITIONAL MATERIAL. CANADA: Granet Lk., N.W.T. $68^{\circ} 42^{\prime}$ N. $125^{\circ} 37^{\prime}$ 'W. 20.VII.1969, G.E. Shewell (1 O', 1 + , ZMUM); Coral Harbour, Southampton Is. 17.VII.1948, G.E. Shewell (1 $\sigma^{7}$, ZMUM); Chesterfield, N.W.T., 3.VIII.1950, J.R. Vockeroth (1 क, ZMUM).

DESCRIPTION. Male, female. Medium-sized flies (4.2-5.7 mm long). 
Head. Frontal vitta blackish in upper part and reddish yellow in lower half or third, matt. Fronto-orbital plate black, greyish dusted. Face, parafacial and gena reddish yellow. Postgena black, greyish dusted. Postcranium black, greyish dusted, covered with black setae in upper third and pale hairs in lower part. 3 orbitals, 2-4 frontals, 1 ocellar, 1 postocellar (short), 1 inner vertical, 1 outer vertical; 2 pairs of vibrissae present. Antenna black. Postpedicel with more or less rounded upper apical corner, about 2.0 times as long as wide. Arista black, basally thickened, bare. Clypeus and proboscis black. Palpus yellow.

Thorax black, greyish dusted. Acrostical hairs in two rows, dorsocentrals $4+3$, including short erect seta on anterior margin of scutum, intra-alars $1+2$, supraalars $1+2$, postpronotals 2, notopleurals 2, postalars 2 . Proepisternum covered with hairs anteriorly, with 1-2 setae near lower margin. Proepimeron with one seta. Anepisternum covered with hairs in posterior half, with 3-4 setae along posterior margin. Katepisternum greyish dusted completely, covered with hairs in posterior half, with 1 strong seta in upper posterior corner. Anepimeron bare. Scutellum black, greyish dusted, with a pair of basal scutellar and a pair of apical scutellar setae.

Legs black, greyish dusted. Fore femur with a row of posterodorsal setae and a row of long and thin ventral setae. Fore tibia with 1 dorsal and $0-1$ posterior/ posteroventral setae, with 1 preapical dorsal/posterodorsal, 1 preapical anterodorsal and 1 apical posterior setae. Mid femur with a row of anterior setae, with 1 preapical posterior and 1 preapical posterodorsal setae. Mid tibia with 1 anterodorsal, 1 posterodorsal and a ring of apical setae. Hind femur with a row of anterodorsal setae and several anteroventral setae in apical half. Hind tibia with 2 anterodorsal, 2 posterodorsal, 1 preapical dorsal, 1 apical/preapical anterodorsal and 1 apical anteroventral setae.

Wing tinged with brownish; veins brown. $\mathrm{R}_{1}$ bare dorsally. Calypters, margins of calypters, and halteres yellowish or brownish.

Abdomen black, greyish dusted. Male sternite 4 as long as wide (Fig. 11). Male sternite 5 with lobes narrowed apically and curved outward (Fig. 17). Epandrium and surstyli as in Figs 23, 29.

DISTRIBUTION. Russia: Chukotka, Tyumen' Oblast. - Europe (Scandinavia), North America.

\section{Trichopalpus (Chaetosa) punctipes (Meigen, 1826)} Figs 2, 12, 18, 24, 30. given.

punctipes Meigen, 1826: 239 (Cordylura). Type-locality: not Recorded as widespread species in Russia [Gorodkov, 1970; Ovchinnikov, 2004, 2005, 2013; Humala, Polevoi, 2009, Ozerov, Barkalov, 2014; Ozerov, Krivosheina, 2014; Bagachanova et al., 2016].

MATERIAL. Altai: Kosh-Agach $\left(49.9975^{\circ} \mathrm{N} 88.6706^{\circ} \mathrm{E}\right), 1,5$ and 30.VII.1964, Nartshuk (4 $\sigma^{7} \sigma^{7}, 2$ 90 , ZISP); Kosh-Agach env. $\left(50.01^{\circ} \mathrm{N} 88.66^{\circ} \mathrm{E}\right), 1750 \mathrm{~m}, 2-4$. VII.2016, N. Vikhrev $\left(5 \sigma^{7} \sigma^{7}\right.$ ZMUM); Chuya River, $20 \mathrm{~km} \mathrm{NW}$ of Kosh-Agach $\left(50.0852^{\circ} \mathrm{N}\right.$
88.4047 ${ }^{\circ} \mathrm{E}$ ), 25-27.VII.2006, A. Ovchinnikov (4 $\sigma^{7} \sigma^{7}$, ZISP); Klyuchevskoe Lake $\left(52.25^{\circ} \mathrm{N} 79.16^{\circ} \mathrm{E}\right), 20 . \mathrm{VI} .2009$, O. Kosterin (1 ${ }_{+}$, ZMUM); Manzherok Lake (51.8252 $\left.{ }^{\circ} \mathrm{N} 85.8127^{\circ} \mathrm{E}\right), 10 . \mathrm{V} .2006$, O. Kosterin (1 $\sigma^{7}, 1$ ㅇ, ZMUM); Kosh-Agach, plato Ukok, 2400 m, Muzdy-Bulak Lake env. (49.26 N 87.65 E), 10-11.VII.2008, A. Barkalov (1 $\sigma^{\top}, 2$ 우, ISEA); the source of the Naryn-Gol River from Kindyktykul' Lake, $2477 \mathrm{~m},\left(49.83^{\circ} \mathrm{N} 89.44^{\circ} \mathrm{E}\right)$, 19.VII.2009, A. Barkalov (1 $\sigma^{7}, 3$ 웅, ISEA); Kurayskiy ridge, 2500-2700 m

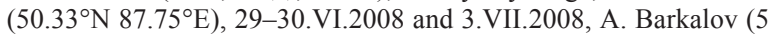
$\sigma^{\top}, 2$, 9 , ISEA and ZMUM); Kolyvanskoe Lake $\left(51.3638^{\circ} \mathrm{N}\right.$ 82.1916 ${ }^{\circ}$ E), 8.IX.2007, O. Kosterin (2 $\sigma^{\top} \sigma^{\top}$, ZMUM); Teletskoe Lake, Artybash, $\left(51.7925^{\circ} \mathrm{N} 87.2594^{\circ} \mathrm{E}\right), 17$. V.2009, V. Zinchenko ( 1 \%, ISEA); Artybash env. (51.796 $\left.{ }^{\circ} \mathrm{N} 87.2654^{\circ} \mathrm{E}\right), 16-18$. VII.2006, Nartshuk, Ovchinnikov (1 $\mathrm{O}^{\mathrm{N}}, 1$, , ZISP); Nizhniy Uymon $\left(51.796^{\circ} \mathrm{N}\right.$ $\left.87.2654^{\circ} \mathrm{E}\right), 31$. VII.1927, N. Gorbunov (1 9 , ZISP); Turochak env. $\left(52.2618^{\circ} \mathrm{N} 87.1239^{\circ} \mathrm{E}\right), 17$. VII.2006, A. Ovchinnikov $\left(2 \sigma^{7} \sigma^{\top}\right.$, ZISP); Ulus-Cherga $\left(51.5191^{\circ} \mathrm{N} 85.4594^{\circ} \mathrm{E}\right), 27$.VII.2008, O. Kosterin $\left(1+\right.$, ZMUM); Amur Oblast: Bol'shoy Never $\left(53.9788^{\circ} \mathrm{N}\right.$ $\left.124.1509^{\circ} \mathrm{E}\right), 7-8 . I X .1974$, Gorodkov (2 ${ }^{7} \sigma^{7}$, ZISP); Klimoutsy $\left(51.4701^{\circ} \mathrm{N} 127.5991^{\circ} \mathrm{E}\right), 31 . \mathrm{VII}$. and 31.VIII.1958, 31.VI. 1959, Zinov'ev (12 $\sigma^{7} \sigma^{7}, 9$ 우, ZISP); same place, 19, 23 and 28.VI.1958, Borisova ( $\sigma^{7}, 2$ 우, ZISP); Simonovo $\left(51.4674^{\circ} \mathrm{N} 127.0033^{\circ} \mathrm{E}\right)$, 12.VII.1959, Zinov'ev ( $1 \sigma^{\top}, 2$ 우, ZISP); Arkhangelsk Oblast: 35 $\mathrm{km}$ ESE of Karpogory (ca. $64^{\circ} \mathrm{N} 44.45^{\circ} \mathrm{E}$ ), Pinega River, 11.VII.1996, Gorodkov (11 $\sigma^{7} \sigma^{7}, 2$ 우, ZISP); Karpogory $\left(63.9995^{\circ} \mathrm{N} 44.45369^{\circ} \mathrm{E}\right), 10 . \mathrm{VII} .1996$, Gorodkov (1 $\sigma^{7}, 3$ 우, ZISP); $70 \mathrm{~km} \mathrm{~N}$ of Nar'yan-Mar (ca. $\left.68.2045^{\circ} \mathrm{N} 53.6278^{\circ} \mathrm{E}\right), 18$.VIII.1978, Gorodkov (1 $\sigma^{7}$, ZISP); $73 \mathrm{~km} \mathrm{NW}$ of Nar'yan-Mar (ca. $67.9814^{\circ} \mathrm{N}$ $\left.51.6083^{\circ} \mathrm{E}\right)$, 3.VIII.1978, Gorodkov (1 $\sigma^{\mathrm{T}}$, ZISP); airport Talagi $\left(64.5973^{\circ} \mathrm{N} 40.7091^{\circ} \mathrm{E}\right), 1$.VIII.1978, Gorodkov (1 + , ZISP); Talagi $\left(64.6206^{\circ} \mathrm{N} 40.6486^{\circ} \mathrm{E}\right), 13$.VIII.1970, Gorodkov (1 O', ZISP); Arkhangelsk $\left(64.5461^{\circ} \mathrm{N} 40.5677^{\circ} \mathrm{E}, 64.5182^{\circ} \mathrm{N} 40.4215^{\circ} \mathrm{E}\right)$, 4.VIII.2010, 7.VIII.2011, D. Gavryushin (3 $\sigma^{7} \sigma^{7}, 3$ 우, ZMUM); Belush'e env. (66.89 $\left.9^{\circ} 47.61^{\circ} \mathrm{E}\right), 24$.VIII.1978, Gorodkov $\left(2 \sigma^{7} \sigma^{\prime \prime}\right.$, 1 ․, ZISP); Kargopol' $\left(61.5035^{\circ} \mathrm{N} 38.9719^{\circ} \mathrm{E}\right), 16$. VII.1982, Gorodkov (3 今 $\sigma^{7}, 2$ qo, ZISP); Mezen' $\left(65.85^{\circ} \mathrm{N} 44.24^{\circ} \mathrm{E}\right), 26-$ 27.VIII.1978, Gorodkov ( $8 \sigma^{\top} \sigma^{\top}, 2$ 우, ZISP); Nizhnyaya Pesha $\left(66.7518^{\circ} \mathrm{N} 47.7605^{\circ} \mathrm{E}\right), 22$.VIII.1978, Gorodkov (7 $\bigcirc^{7} \bigcirc^{7}, 3$ 우, ZISP); Solvychegovsk $\left(61.3421^{\circ} \mathrm{N} 46.9132^{\circ} \mathrm{E}\right)$, 2.IX.1961, Gorodkov (1 +, ZISP); same place, 12-14.VIII.2010, D. Gavryushin (11 $\sigma^{7} \sigma^{\top}, 20$ 우, ZMUM); Nar'yan-Mar $\left(67.6317^{\circ} \mathrm{N} 52.9857^{\circ} \mathrm{E}\right)$, 2.VIII.1978, Gorodkov (5 $\sigma^{7} \sigma^{7}, 2$ 0 , ZISP); same place, 67.VII.2008, A.L. Ozerov, N. Vikhrev (2 ○ $\sigma^{7}, 4$ 우, ZMUM); Kashin I. $\left(68.2420^{\circ} \mathrm{N} 53.8567^{\circ} \mathrm{E}\right), 10 . \mathrm{VII} .2008$, A.L. Ozerov (1 $\mathrm{O}^{\prime \prime}$, ZMUM); Solovetskiy I. $\left(65.0805^{\circ} \mathrm{N} 35.6863^{\circ} \mathrm{E}\right), 27 . \mathrm{VII} .19759$, Gorodkov (1 $\sigma^{7}, 2$ of, ZISP); Velikovisochnoe $\left(67.255^{\circ} \mathrm{N}\right.$ $\left.52.0328^{\circ} \mathrm{E}\right)$, 18.VIII.1978, Gorodkov (5 $\sigma^{\top} \sigma^{\top}, 3$ 우, ZISP); Astrakhan' Oblast: Baskunchak salt lake $\left(48.193^{\circ} \mathrm{N} 46.813^{\circ} \mathrm{E}\right), 2-$ 4.V.2010, K. Tomkovich (2 $\sigma^{7} \sigma^{7}$, ZMUM); Bashkiria: Nura River $\left(54.0515^{\circ} \mathrm{N} 58.2688^{\circ} \mathrm{E}\right), 607 \mathrm{~m}, 8$.VIII.2012, D. Gavryushin (3 90 , ZMUM); Buryatia: Barguzinskiy Reserve (ca. $54.35^{\circ} \mathrm{N} 109.51^{\circ} \mathrm{E}$ ), 20-31.VII.1965, Negrobov (2 $\bigcirc^{7} \sigma^{7}, 6$ OP, ZISP); Barguzinskiy Reserve, Sosnovka env. (ca. $\left.54.1821^{\circ} \mathrm{N} 109.5396^{\circ} \mathrm{E}\right), 1$ and 8.VIII.1962, Gorodkov ( $2 \bigcirc^{7} \sigma^{7}, 1$, ZISP); Baykal Lake, Pokoyniki env. $\left(53.713^{\circ} \mathrm{N}\right.$ $\left.109.049^{\circ} \mathrm{E}\right), 24$.VII.1962, Gorodkov (5 $\sigma^{\top} \sigma^{\top}, 2$ 우, ZISP); Khargun, $6 \mathrm{~km} \mathrm{E}$ of Kyren $\left(51.6837^{\circ} \mathrm{N} 102.1326^{\circ} \mathrm{E}\right)$, Sayany, 11.VII.1965, Gorodkov (2 $\sigma^{7} \sigma^{\top}, 1$ ㅇ, ZISP); Kyren env. (51.6837 $\left.\mathrm{N} 102.1326^{\circ} \mathrm{E}\right)$, 11.VII.1965, Gorodkov (1 +, ZISP); Mondy env. $\left(51.6758^{\circ} \mathrm{N}\right.$ $\left.100.9925^{\circ} \mathrm{E}\right), 18$.VIII.1962, 15, 19 and 26.VII.1965, Gorodkov (10 $\Im^{7} \sigma^{\top}, 7$ 우, ZISP); Naushki (50.3852 $\left.{ }^{\circ} \mathrm{N} 106.1083^{\circ} \mathrm{E}\right), 26$. VIII.1962, Gorodkov (1 9, ZISP); the upper reaches of the Irkut River near Il'chir Lake $\left(51.9611^{\circ} \mathrm{N} 100.9527^{\circ} \mathrm{E}\right), 7$. VIII.2012, A. Medvedev (1 $\sigma^{7}, 1$ q, ZMUM); Ust' Kiran env. $\left(50.4183^{\circ} \mathrm{N} 106.8138^{\circ} \mathrm{E}\right)$, 29.VII.1908, Khomse (5 $\sigma^{7} \sigma^{\top}, 2$, 2 , ZISP); Chelyabinsk Oblast: Taganay $\left(55.2702^{\circ} \mathrm{N} 59.8012^{\circ} \mathrm{E}\right), 18-24 . V I I .2008$, K. Tomkovich (1 $\Im^{7}$, ZMUM); Turgoyak Lake env. (55.1385 $\left.{ }^{\circ} \mathrm{N} 60.0947^{\circ} \mathrm{E}\right), 26-$ 31.VIII.2008, K. Tomkovich (1 $\sigma^{7}$, ZMUM); Chukotka: Apapel'khin (ca. $\left.69.7644^{\circ} \mathrm{N} 170.6176^{\circ} \mathrm{E}\right)$, 1.VII.1972, Gorodkov (1 O ${ }^{\top}$, ZISP); Bilibino $\left(68.0584^{\circ} \mathrm{N} 166.4463^{\circ} \mathrm{E}\right), 5$.VII. 1971 , Gorodkov (1 ㅇ, ZISP); Markovo (ca. $\left.64.6805^{\circ} \mathrm{N} 170.4127^{\circ} \mathrm{E}\right), 18$. VIII.1966, Gorodkov (33

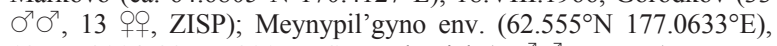
13.VII.2014, 29.VII.2015, P.S. Tomkovich (5 $\sigma^{\top} \sigma^{\top}$, ZMUM); Irkutsk Oblast: Novochunka $\left(56.1144^{\circ} \mathrm{N} 99.2735^{\circ} \mathrm{E}\right), 5 . \mathrm{VI} .1957$, Gorod- 

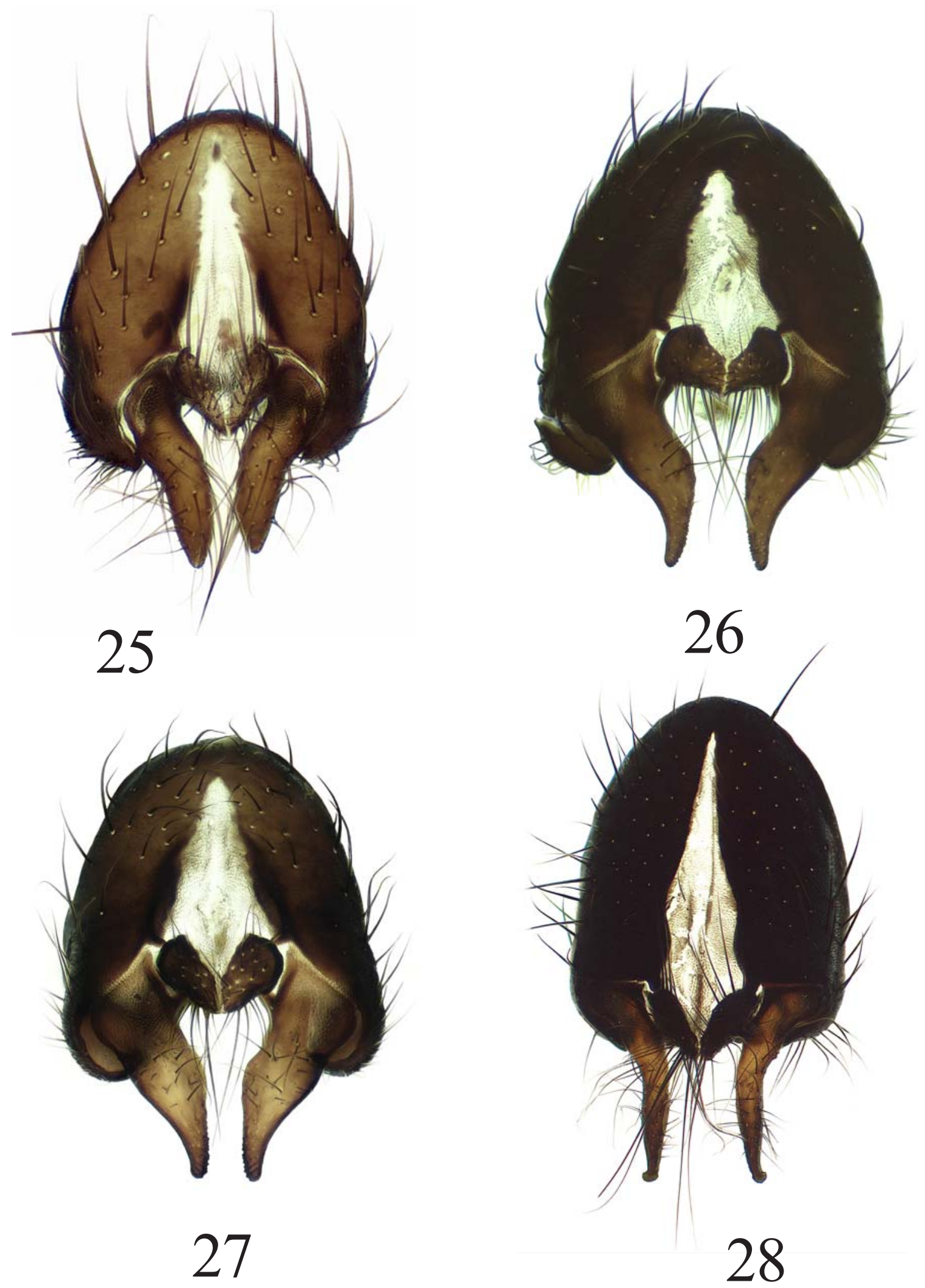

Figs 25-28. Epandrium, cerci and surstyli, dorsal view of Trichopalpus spp.: $25-$ T. fraternus (Meigen); $26-T$. lacteipennis (Ringdahl); $27-$ T. nearcticus (Vockeroth); $28-$ T. nigribasis (Curran).

Рис. 25-28. Эпандрий, церки и сурстили, сверху видов Trichopalpus: $25-T$. fraternus (Meigen); $26-$ T. lacteipennis (Ringdahl); $27-$ T. nearcticus (Vockeroth); $28-T$. nigribasis (Curran). 
kov $\left(1 \sigma^{\prime}\right.$, ZISP); Padun $\left(56.2931^{\circ} \mathrm{N} 101.7117^{\circ} \mathrm{E}\right), 15-29 . \mathrm{VI} ., 2-$ 16.VII.1956, Monchadskiy (29 $\sigma^{7} \sigma^{7}, 22$ 우, ZISP); Kaluga and Kaluga Oblast: $54.5374^{\circ} \mathrm{N} 36.2587^{\circ} \mathrm{E}, 28 . \mathrm{VII} .1979$, Gorodkov (1 $\mathrm{O}^{7}, 1$ ㅇ, ZISP); Borovsk $\left(55.2095^{\circ} \mathrm{N} 36.4759^{\circ} \mathrm{E}\right)$, 13.VIII.20103, D. Gavryushin (2 우, ZMUM); Kamchatka Krai: Klyuchevskoe [=Kluchi] $\left(56.3226^{\circ} \mathrm{N} 160.8295^{\circ} \mathrm{E}\right), 5 . \mathrm{VI} .1909$, A. Derzhavin $(1$ o ZISP); Kamenskoe $\left(62.4675^{\circ} \mathrm{N} 166.2063^{\circ} \mathrm{E}\right), 31 . \mathrm{VII} .1973$, Negrobov (1 9 , ZISP); Korf $\left(60.3768^{\circ} \mathrm{N} 166.0233^{\circ} \mathrm{E}\right)$, 29.VI.1959, Gorodkov (2 우, ZISP); Kozyrevsk $\left(56.0487^{\circ} \mathrm{N} 159.8703^{\circ} \mathrm{E}\right), 16 . \mathrm{VII} .1985$, V Zlobin (1 $\sigma^{7}, 1$, , ZISP); Sivuchiy Is. $\left(56.3605^{\circ} \mathrm{N} 162.708^{\circ} \mathrm{E}\right.$ ), 26.VI.1908, A. Derzhavin (1 $\sigma^{7}, 1$ ㅇ, ZISP); Ust'-Bol'sheretsk $\left(52.8238^{\circ} \mathrm{N} 156.2788^{\circ} \mathrm{E}\right)$, 13.IX.1975, Negrobov (1 $0^{7}$, ZISP); Ust'Kamchatsk $\left(56.2295^{\circ} \mathrm{N} 162.4692^{\circ} \mathrm{E}\right), 10 . \mathrm{VIII} .1930$, E. Gur'yanova (1 , ZISP); Zhupanovo $\left(54.0828^{\circ} \mathrm{N} 159.9748^{\circ} \mathrm{E}\right), 30 . \mathrm{VII} .1985$, V. Zlobin (1 $\mathrm{O}^{\prime}$, ZISP); Karelia: Kaskesnavolok $\left(61.594^{\circ} \mathrm{N} 33.3235^{\circ} \mathrm{E}\right)$, 20.VI.1979, Gorodkov (3 O $^{7} 0^{7}$, ZISP); Kizhi $\left(62.084^{\circ} \mathrm{N} 35.211^{\circ} \mathrm{E}\right)$, 19.VI.1979, Gorodkov ( $3 \mathrm{O}^{\top} \mathrm{O}^{\top}, 2$ 오, ZISP); Petrazovodsk $\left(61.7889^{\circ} \mathrm{N}\right.$ 34.3444 ${ }^{\circ}$ E), 17.VI.1979, Gorodkov (5 O $^{\top} \mathrm{O}^{7}, 5$ 우, ZISP); Poyakonda $\left(66.5898^{\circ} \mathrm{N} 33.8210^{\circ} \mathrm{E}\right), 8$ 8.VII.2010, A.L. Ozerov (1 $\bigcirc^{7}$, ZMUM); Primorskiy $\left(66.5493^{\circ} \mathrm{N} 33.1338^{\circ} \mathrm{E}\right), 3 . \mathrm{VII} .2010$, A.L. Ozerov $\left(7 \mathrm{O}^{7} \mathrm{O}^{\prime \prime}\right.$ 4 우, ZMUM); Pudozh $\left(66.8047^{\circ} \mathrm{N} 36.5658^{\circ} \mathrm{E}\right), 18$.VII.1982, Gorodkov $\left(4 \bigcirc^{7} \sigma^{7}, 1\right.$ \% , ZISP); Sumskoy posad $\left(64.2383^{\circ} \mathrm{N} 35.4084^{\circ} \mathrm{E}\right)$, 27.VII.1996, Gorodkov (1 $0^{7}, 1$ ㅇ, ZISP); Kemerov Oblast: Novokuznetsk env. $\left(55.7572^{\circ} \mathrm{N} 87.1488^{\circ} \mathrm{E}\right)$, 29.VI.2011, O. Kosterin $\left(2{\sigma^{7}}^{7} \sigma^{7}, 1\right.$,, ZMUM); Khabarovsk Krai: Bulgino env. $\left(59.3718^{\circ} \mathrm{N}\right.$ 143.1475² E), 29.VIII.1987, Gorodkov ( $10^{7}, 1$ ㅇ, ZISP); Khingari [=Gurskoe] $\left(50.3123^{\circ} \mathrm{N} 138.1003^{\circ} \mathrm{E}\right), 2 . \mathrm{V} .1913$, Soldatov (2 우 ZISP); Litvintsevo (ca. $51.1328^{\circ} \mathrm{N} 138.5494^{\circ} \mathrm{E}$ ), 24.VII.1911, V.K Soldatov $\left(4 \sigma^{7} \sigma^{7}, 1\right.$ ․, ZISP); Nizhnetambovskoe $\left(50.9197^{\circ} \mathrm{N}\right.$ $\left.138.1911^{\circ} \mathrm{E}\right), 15 . \mathrm{VI} .19110$, Soldatov (1 $\mathrm{O}^{7}$, ZISP); Tsimmermanovka env. $\left(51.3393^{\circ} \mathrm{N} 139.2463^{\circ} \mathrm{E}\right), 20 . \mathrm{VII} .-2 . \mathrm{VIII} .1911$, V.K. Soldatov $\left(1 \mathrm{O}^{\top}, 1\right.$ ㅇ, ZISP); Khakassia: Beljo salt lake env. $\left(54.65^{\circ} \mathrm{N} 90.18^{\circ} \mathrm{E}\right)$, $382 \mathrm{~m}, 1-3$. VII.2011, K. Tomkovich $\left(20^{7} \sigma^{7}\right.$, ZMUM); Shira salt lake env. $\left(54.485^{\circ} \mathrm{N} 90.224^{\circ} \mathrm{E}\right), 350-355 \mathrm{~m}, 21-24 . V I .2011, \mathrm{~K}$. Tomkovich (1 $\mathrm{O}^{7}$, ZMUM); Kubayka $\left(52.33^{\circ} \mathrm{N} 89.82^{\circ} \mathrm{E}\right), 10$ 13.VII.2017, N. Vikhrev (1 O', ZMUM); Komi: 3 km E of Yaksha $\left(61.8233^{\circ} \mathrm{N} 56.8213^{\circ} \mathrm{E}\right), 5$.VIII.1985, Gorodkov $\left(5 \mathrm{O}^{7} 0^{7}, 5\right.$ 우, ZISP); $3 \mathrm{~km} \mathrm{~N}$ of Ust-Tsilma (ca. $\left.65.45^{\circ} \mathrm{N} 52.11^{\circ} \mathrm{E}\right), 10 . \mathrm{VIII} .1978$, Gorodkov (1 $0^{7}$, ZISP); Blagoevo $\left(63.41^{\circ} \mathrm{N}\right.$ 47.95 $\left.{ }^{\circ} \mathrm{E}\right)$, 13.VII.1996, Gorodkov $\left(1 \mathrm{O}^{7}, 1\right.$ ㅇ, ZISP); Inta $\left(66.04^{\circ} \mathrm{N} 60.17^{\circ} \mathrm{E}\right), 6$. VIII.1985, Gorodkov $\left(10^{\prime}\right.$, ZISP); Seida $\left(67.05^{\circ} \mathrm{N} 63.09^{\circ} \mathrm{E}\right), 23$.VII. 2010 , N. Vikhrev $\left(2 \mathrm{O}^{7} \mathrm{O}^{7}, 2\right.$ Oᄋ, ZMUM); Vorkuta $\left(67.5^{\circ} \mathrm{N} 64.0^{\circ} \mathrm{E}\right), 19-25 \mathrm{VII}, 2010$ N. Vikhrev $\left(10^{7}, 1\right.$ \%, ZMUM); Shchel'yabozh $\left(66.29^{\circ} \mathrm{N} 56.45^{\circ} \mathrm{E}\right)$, 14.VIII.1978, Gorodkov (5 $0^{7} \mathrm{O}^{7}$, ZISP); Shchel'yayur $\left(65.33^{\circ} \mathrm{N}\right.$ $\left.53.43^{\circ} \mathrm{E}\right)$, 12.VIII.1978, Gorodkov ( $1 \mathrm{O}^{7}, 1$ ㅇ, ZISP); Sivaya Maska Station $\left(66.6756^{\circ} \mathrm{N} 62.5699^{\circ} \mathrm{E}\right), 5 \mathrm{~km} \mathrm{NW}, 6 . \mathrm{VII} .1961$, Gorodkov (1 ㅇ, ZISP); Yaksha env. (ca. $61.8233^{\circ} \mathrm{N} 56.8213^{\circ} \mathrm{E}$ ), 5.VIII.1985, 14.VIII.1989, Gorodkov (5 $\sigma^{7} \sigma^{7}, 6$ 6 , ZISP); Krasnoyarsk Krai: "Stolby" $\left(55.970^{\circ} \mathrm{N} 92.442^{\circ} \mathrm{E}, 55.963^{\circ} \mathrm{N} 92.745^{\circ} \mathrm{E}\right), 31$. VII.2009 and 18-19.VI.2011, K. Tomkovich (4 $0^{7} \sigma^{7}$, ZMUM); Krasnoyarsk, Bizaikha $\left(56.0205^{\circ} \mathrm{N}, 93.0642^{\circ} \mathrm{E}\right)$, 1.IX.1928, Levchuk (1 $0^{7}$, ZISP) Krasnoyarsk (56.037 $\left.{ }^{\circ} \mathrm{N} 92.803^{\circ} \mathrm{E}\right), 27-29$. VII.2009, O. Kosterin (1 $\mathrm{O}^{1}$, ZMUM); Noril'sk env. (ca. $\left.69.3396^{\circ} \mathrm{N} 88.2147^{\circ} \mathrm{E}\right), 21 . \mathrm{VIII} .1971$, 20.VIII.1973, Gorodkov (6 $\mathrm{O}^{7} \mathrm{O}^{7}$, ZISP); Sorokino $\left(55.8822^{\circ} \mathrm{N}\right.$ 93.3909 ${ }^{\circ}$ E), 12.VI.1897, Vagner (1 ${ }^{\circ}$, ZISP); Kursk Oblast: Streletskaya step' $\left(51.5795^{\circ} \mathrm{N} 36.0870^{\circ} \mathrm{E}\right), 20-21$. VII.2007, A. Ozerov (1 $\sigma^{7}$, ZMUM); Leningrad Oblast: Luga (ca. $58.73^{\circ} \mathrm{N} 29.84^{\circ} \mathrm{E}$ ), 14.VII.1952, 12-17.VIII.1952, A. Stackelberg (3 $0^{7} 0^{7}, 4$ 우, ZISP) Rozhdestveno $\left(59.3228^{\circ} \mathrm{N} 29.9465^{\circ} \mathrm{E}\right), 9 . \mathrm{VI}$. and 28.VIII.1956, A. Stackelberg (3 $0^{7} \mathrm{O}^{7}, 6$ 우으. ZISP); Tolmachevo $\left(58.8565^{\circ} \mathrm{N}\right.$ $\left.29.8956^{\circ} \mathrm{E}\right)$, 24.VIII.1953, A. Stackelberg (2 우, ZISP); same place, 17.VIII.1935, Rohdendorf (1 $\sigma^{7}$, ZISP); Yashchera $\left(58.8945^{\circ} \mathrm{N}\right.$ $29.8206^{\circ}$ E), 26.V., 13.VI. and 5.VIII.1957, 20.VIII.1967, A. Stackelberg (4 $\mathrm{O}^{7} \mathrm{O}^{7}, 7$ 우, ZISP); Magadan Oblast: Gizhiga $\left(61.9487^{\circ} \mathrm{N}\right.$ $\left.160.3772^{\circ} \mathrm{E}\right)$, 6.IX.1987, Gorodkov (2 $0^{7} 0^{7}, 2$ 우, ZISP); Moscow and Moscow Oblast: Abramtsevo $\left(56.2304^{\circ} \mathrm{N} 37.9564^{\circ} \mathrm{E}\right)$, 21.VI.1954, 20.VII.1957, E.S. Smirnov (2 9 , ZMUM); Andreevskoe $\left(55.9783^{\circ} \mathrm{N} 35.5885^{\circ} \mathrm{E}\right), 10$. VIII.2007, A.L. Ozerov $\left(1 \mathrm{O}^{7}, 1\right.$, ZMUM); Burtsevo $\left(55.9877^{\circ} \mathrm{N} 35.6008^{\circ} \mathrm{E}\right)$, 2.IX.2007, A.L. Ozerov (1 Oㄱ, ZMUM); Golitsyno (55.6496 $\left.{ }^{\circ} \mathrm{N} 37.0117^{\circ} \mathrm{E}\right)$, 9.VII.1977, A Shatalkin $\left(10^{\top}, 2\right.$ 우, ZMUM); Dmitrov env. $\left(56.3163^{\circ} \mathrm{N} 37.7258^{\circ} \mathrm{E}\right)$, 20.VI., 2.VII., 16. and 29.VIII.2007, N. Vikhrev (4 $\mathrm{O}^{7} \mathrm{O}^{7}$, ZMUM); Kostino env. $\left(53.35^{\circ} \mathrm{N} 37.81^{\circ} \mathrm{E}\right), 16 . \mathrm{VIII} .2013$, N. Vikhrev (1 ${ }^{\prime}$,
ZMUM); Ivanovskoe $\left(55.9772^{\circ} \mathrm{N} 35.5874^{\circ} \mathrm{E}, 55.9256^{\circ} \mathrm{N} 35.6056^{\circ} \mathrm{E}\right)$, 17.VII.2007, 8.VIII.2009, A.L. Ozerov (2 $0^{7} \mathrm{O}^{7}, 1$ +, ZMUM); Izmaylovo $\left(55.7867^{\circ} \mathrm{N} 37.8350^{\circ} \mathrm{E}, 55.8023^{\circ} \mathrm{N} 37.8440^{\circ} \mathrm{E}\right)$, 5.VI., 2.VII.1983, 20.VI.2007, A.L. Ozerov (4 $0^{7} 0^{7}, 1$ 9, ZMUM); Kosino $\left(55.7214^{\circ} \mathrm{N} 37.8476^{\circ} \mathrm{E}\right), 12 . \mathrm{VI} .1921$, B. Rodendorf (1 $\mathrm{O}^{\mathrm{T}}$, ZMUM); Mamontovka $\left(55.9991^{\circ} \mathrm{N} 37.8164^{\circ} \mathrm{E}\right), 16$. VII., 15.VIII.1936, E. Smirnov $\left(1 \bigcirc^{7}, 1\right.$ ․, ZMUM); Naro-Fominsk $\left(55.3574^{\circ} \mathrm{N} 36.7361^{\circ} \mathrm{E}\right)$, 22.VI.2013, D. Gavryushin (2 $0^{7} 0^{7}, 2$ 우, ZMUM); Ozhigovo $\left(55.4533^{\circ} \mathrm{N} 36.8847^{\circ} \mathrm{E}\right), 26$. VII.2010, D. Gavryushin (1 $0^{\top}$, ZMUM); Pushchino $\left(54.8361^{\circ} \mathrm{N} 37.6232^{\circ} \mathrm{E}\right), 31 . \mathrm{V} .1984$, M. Krivosheina $(1$

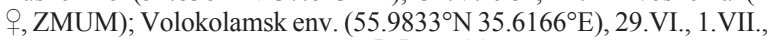
11.VII.1999, A.L. Ozerov (5 $0^{7} \sigma^{7}, 2$ 오, ZMUM); Stepan'kovo $\left(56.0045^{\circ} \mathrm{N} 35.6247^{\circ} \mathrm{E}\right), 9$.VII.2006, 3.VI.2007, A.L. Ozerov ( $80^{7} \sigma^{7}$, 8 ㅇ, ZMUM); Tsaritsyno $\left(55.6167^{\circ} \mathrm{N} 37.6838^{\circ} \mathrm{E}\right), 11 . \mathrm{VIII} .2009, \mathrm{~K}$. Tomkovich (1 ㅇ, ZMUM); Yur'evo $\left(56.0067^{\circ} \mathrm{N} 35.5460^{\circ} \mathrm{E}\right)$, 17.VII.2010, A.L. Ozerov ( $10^{7}, 1$,, ZMUM); Yakshino (55.9306 N $35.5771^{\circ}$ E), 1.VIII.2005, A.L. Ozerov (1 $\sigma^{\prime}$, ZMUM); Murmansk Oblast: Dal'nie Zelentsy $\left(69.1171^{\circ} \mathrm{N} 36.0625^{\circ} \mathrm{E}\right), 10 . \mathrm{VIII} .1981$, Gorodkov (1 $\sigma^{7}$, ZISP); Khibiny Station $\left(67.6736^{\circ} \mathrm{N} 33.2126^{\circ} \mathrm{E}\right)$, 27.VIII.1928, Cheburova (1 $\bigcirc^{7}$, ZISP); Krasnoshchel'e $\left(67.351^{\circ} \mathrm{N}\right.$ $\left.37.0453^{\circ} \mathrm{E}\right), 18$.VIII.1981, Gorodkov (4 O $^{\top} \mathrm{O}^{\top}, 5$ ㅇ, ZISP); Lovozero $\left(68.0057^{\circ} \mathrm{N} 35.0161^{\circ} \mathrm{E}\right), 14-16 . \mathrm{VIII} .1981$, Gorodkov $\left(7 \mathrm{O}^{\mathrm{T}} \mathrm{O}^{\mathrm{T}}, 4\right.$ 우, ZISP); Murmansk env, $\left(68.9798^{\circ} \mathrm{N} 33.1148^{\circ} \mathrm{E}, 68.9799^{\circ} \mathrm{N}\right.$ $\left.33.1510^{\circ} \mathrm{E}, 68.9767^{\circ} \mathrm{N} 33.1199^{\circ} \mathrm{E}\right), 1^{\circ}-21 . \mathrm{VII} .2011$, A. Ozerov, D. Gavryushin (5 $0^{7} \mathrm{O}^{7}, 4$ 우, ZMUM); Tumannyy $\left(68.8836^{\circ} \mathrm{N}\right.$ $\left.35.6932^{\circ} \mathrm{E}\right)$, 3.VIII.1981, Gorodkov (5 $0^{7} \sigma^{7}, 1$ ㅇ, ZISP); Varzuga $\left(66.3925^{\circ} \mathrm{N} 36.5812^{\circ} \mathrm{E}\right), 16 . \mathrm{VIII} .1995$, Gorodkov (4 $\mathrm{O}^{7} \mathrm{O}^{7}$, ZISP); Nizhegorod Oblast: Dzerzhinsk $\left(56.21^{\circ} \mathrm{N} 43.62^{\circ} \mathrm{E}\right), 16 . \mathrm{VIII} .2009$, N. Vikhrev (2 $\bigcirc \circ$, ZMUM); Novosibirsk and Novosibirsk Oblast: $\left(54.8250^{\circ} \mathrm{N} 83.1141^{\circ} \mathrm{E}, 54.75^{\circ} \mathrm{N} 83.01^{\circ} \mathrm{E}, 54.8452^{\circ} \mathrm{N} 83.0577^{\circ} \mathrm{E}\right)$, 14.VI.2006, 11.V.2008, 19 and 21.VI.2008, 18.VI.2009, O. Koste$\operatorname{rin}\left(16 \mathrm{O}^{\top} \mathrm{O}^{7}, 7\right.$ 우, $\left.\mathrm{ZMUM}\right)$; Achair monestry $\left(54.6633^{\circ} \mathrm{N} 73.8194^{\circ} \mathrm{E}\right)$, 22.VI.2006, O. Kosterin (1, , ZMUM); Inya River $\left(55.0^{\circ} \mathrm{N} 83.2^{\circ} \mathrm{E}\right)$, 22.VII.2012, O. Kosterin (1 $\sigma^{7}$, ZMUM); Zherebtsovo env. $\left(55.125833^{\circ} \mathrm{N} 83.256111^{\circ} \mathrm{E}\right), 22 . V I .2006$, O. Kosterin $\left(2 \mathrm{O}^{7} \mathrm{O}^{7}\right.$, ZMUM); Koynikha $\left(54.5689^{\circ} \mathrm{N} 83.2525^{\circ} \mathrm{E}\right), 13 . \mathrm{VIII} .1977$, Gorodkov $\left(6 \bigcirc^{7} \sigma^{7}, 5\right.$ ofo, ZISP); Orlovka env. $\left(59.93^{\circ} \mathrm{N} 76.33^{\circ} \mathrm{E}\right)$, 16.VII.2015, O. Kosterin ( $1 \bigcirc^{7}, 1$, ZMUM); Omsk and Omsk Oblast: $\left(54.9697^{\circ} \mathrm{N} 73.3605^{\circ} \mathrm{E}, 54.86^{\circ} \mathrm{N} 73.36^{\circ} \mathrm{E}\right), 24$ and 26.VI.2008, 23.V.2012, O. Kosterin (5 $\sigma^{7} \sigma^{7}, 7$ Oᄋ, ZMUM); Krugloe Lake $\left(54.89^{\circ} \mathrm{N} 73.36^{\circ} \mathrm{E}\right)$, 24.VII.2012, O. Kosterin $\left(2 \sigma^{7} \mathrm{O}^{7}\right.$, ZMUM); Irtysh River env. $\left(54.99^{\circ} \mathrm{N} 73.32^{\circ} \mathrm{E}\right), 31 \mathrm{~V} .2006,6-$ 8.VI.2007, 22.VII.2011, O. Kosterin (10 $\sigma^{7} \sigma^{7}, 14$ of , ZMUM); Orenburg Oblast: $10 \mathrm{~km}$ E of Tashla $\left(51.771^{\circ} \mathrm{N} 52.8608^{\circ} \mathrm{E}\right), 6-$ 8.VIII.2004, Nartshuk (2 90 , ZISP); $10 \mathrm{~km} \mathrm{NE}$ of Svetlyy (ca. $\left.50.8695^{\circ} \mathrm{N} 60.9767^{\circ} \mathrm{E}\right), 8-10 . \mathrm{VIII} .2004$, Nartshuk $\left(4 \mathrm{O}^{7} \mathrm{O}^{7}, 4\right.$ 우, ZISP); Zhetykol' Lake (ca. $\left.51.0334^{\circ} \mathrm{N} 60.9016^{\circ} \mathrm{E}\right), 10-12 . \mathrm{VIII} .2004$, Nartshuk (2 0 , ZISP); Perm' Oblast: Kaman, Sylva River (ca. $\left.58.0276^{\circ} \mathrm{N} 56.7789^{\circ} \mathrm{E}\right), 26 . \mathrm{VII} .1997$, Gorodkov (2 $\mathrm{O}^{7} \mathrm{O}^{7}, 1$ ㅇ, ZISP); Primorsky Krai: Gornye Klyuchi $\left(45.25^{\circ} \mathrm{N} 133.50^{\circ} \mathrm{E}\right), 6-7$ VII 2014 , N. Vikhrev (1 $0^{7}$, ZMUM); Kamenushka (43.6342 ${ }^{\circ} \mathrm{N} 132.2220^{\circ}$ E), 22-24.VI.2014, N. Vikhrev (1 $\mathrm{O}^{7}$, ZMUM); Khanka Lake $\left(44.825^{\circ} \mathrm{N}\right.$ 1312.02 ${ }^{\circ}$ E), 15-19.VII.2018, N. Vikhrev (1 $0^{\top}$, ZMUM); Nikol'skUssuriyskiy [= Ussuriysk] env. (ca. $43.8025^{\circ} \mathrm{N} 131.9533^{\circ} \mathrm{E}$ ), 14.VIII.1901, Plokhitskiy (1 $\mathrm{O}^{7}$, ZISP); Santakheza [=Novosel'skoe] $\left(44.775^{\circ} \mathrm{N} 132.693^{\circ} \mathrm{E}\right), 6 . V I .1970$, Pinsker (1 $\sigma^{7}$, ZISP); Yakovlevka $\left(44.4229^{\circ} \mathrm{N} 133.4742^{\circ} \mathrm{E}\right), 15$. VI.1926, Dyakonov, Filip'ev $\left(1 \mathrm{O}^{7}\right.$, ZISP); Ryazan' Oblast: Kasimov env. $\left(54.94^{\circ} \mathrm{N} 41.34^{\circ} \mathrm{E}, 54.969^{\circ} \mathrm{N}\right.$ 41.327 ${ }^{\circ}$ ) , 17-19.VI. and 21-24.VII.2013, N. Vikhrev (2 $0^{7} 0^{7}, 2$ 우, ZMUM); Sakhalin Oblast: Sakhalin Is., Aleksandrovsk-Sakhalinskiy $\left(50.9054^{\circ} \mathrm{N} 142.1654^{\circ} \mathrm{E}\right), 15-30$.VI.1881, Nikol'skiy (1 $ᄋ$ ZISP); Zelenyy Is. $\left(43.51^{\circ} \mathrm{N} 146.137^{\circ} \mathrm{E}\right), 2$.VIII.1955, Violovich $(2$ $\mathrm{O}^{7} \sigma^{\top}, 3$ 우, ZISP); Samara Oblast: Bakhilova Polyana $\left(53.4364^{\circ} \mathrm{N}\right.$ $\left.49.6633^{\circ} \mathrm{E}\right), 23-24 . V I .2006$, A. Ovchinnikov (1 $\sigma^{7}, 1$ ㅇ, ZISP); Sverdlovsk Oblast: Bobrovskoe $\left(56.6794^{\circ} \mathrm{N} 60.9685^{\circ} \mathrm{E}\right)$, 22.VII.1977, Gorodkov (1 O', ZISP); Tatarstan: Volzhsko-Kamskiy Reserve, Saraly $\left(55.2702^{\circ} \mathrm{N} 49.2666^{\circ} \mathrm{E}\right), 29 . \mathrm{V} .2005$, Basov (1 , ZMUM); Tomsk Oblast: Basandayka $\left(56.2832^{\circ} \mathrm{N} 85.4897^{\circ} \mathrm{E}\right)$, 23.VI.1967, Gorodkov (1 $\mathrm{O}^{7}$, ZISP); Tomsk $\left(56.4985^{\circ} \mathrm{N} 84.9964^{\circ} \mathrm{E}\right)$, Gorodok, 22.VI.1967, Gorodkov (5 $0^{\top} \mathrm{O}^{7}, 4$ OP, ZISP); Tuva: Uyuk River $\left(52.07^{\circ} \mathrm{N} 94.04^{\circ} \mathrm{E}\right), 800 \mathrm{~m}, 1-3$. VII.2017, N. Vikhrev $\left(2 \mathrm{O}^{7} \mathrm{O}^{7}\right.$, ZMUM); Tver' Oblast: Dmitrovo $\left(56.5738^{\circ} \mathrm{N} 36.1594^{\circ} \mathrm{E}\right)$, 9.VII.1936, E. Smirnov $\left(2 \mathrm{O}^{7} \mathrm{O}^{7}, 1\right.$,, ZMUM); Volgo Lake $\left(56.8766^{\circ} \mathrm{N}\right.$ 

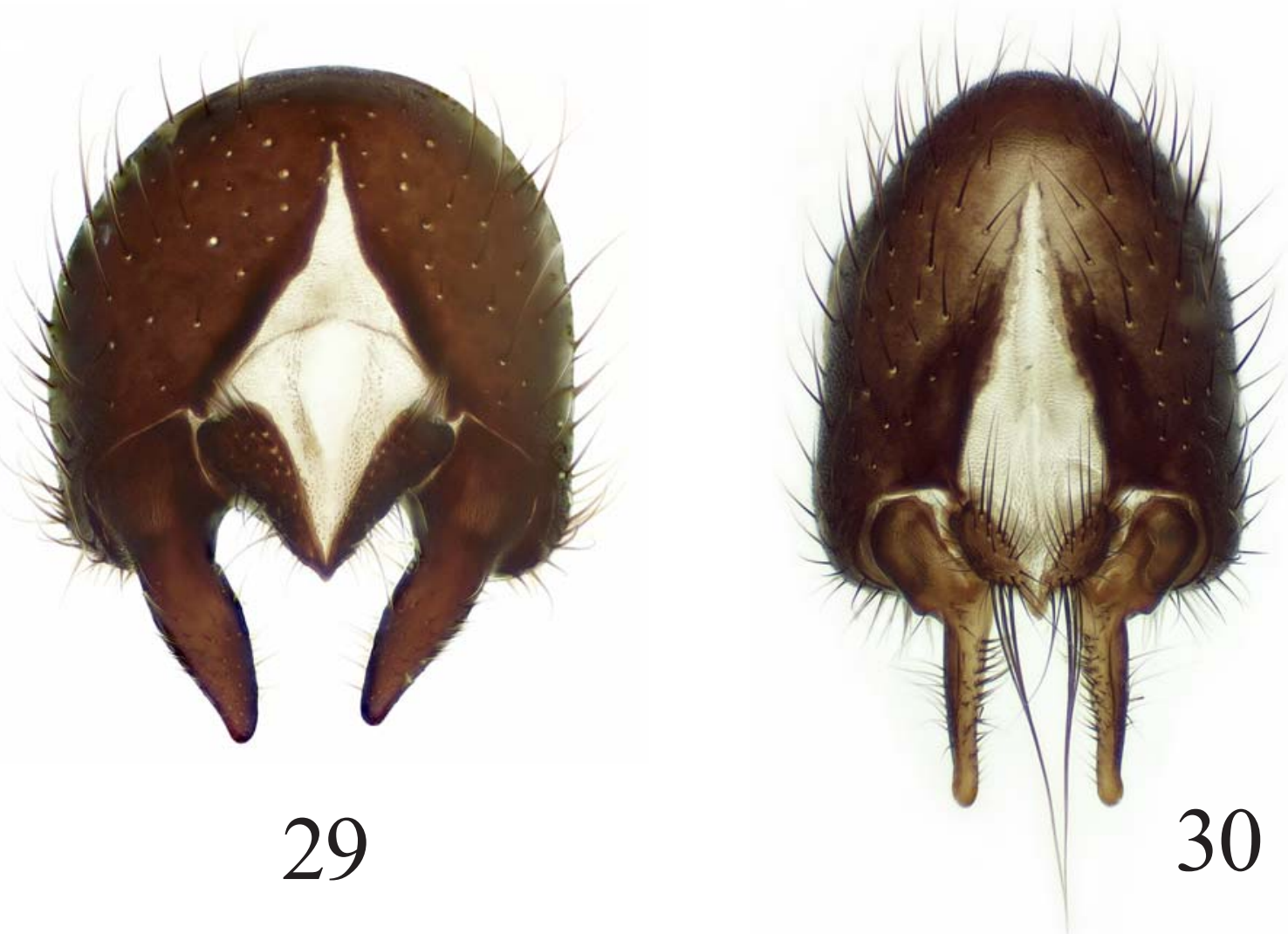

Figs 29-30. Epandrium, cerci and surstyli, dorsal view of Trichopalpus spp.: $29-$ T. obscurellus (Zetterstedt); $30-$ T. punctipes (Meigen).

Рис. 29-30. Эпандрий, церки и сурстили сверху видов Trichopalpus: $29-$ T. obscurellus (Zetterstedt); $30-$ T. punctipes (Meigen).

33.2439²), 18-19.VIII.2011, A.L. Ozerov (3 O $^{7} \mathrm{O}^{7}$, ZMUM); Ostashkov $\left(57.1408^{\circ} \mathrm{N} 33.1636^{\circ} \mathrm{E}\right)$, 13.VII.1939, V. Polezhaev, B. Rohdendorf (7 $O^{7} O^{7}, 5$ 우, ZMUM); Tyumen' Oblast: $\left(63.818^{\circ} \mathrm{N}\right.$ $\left.59.562^{\circ} \mathrm{E}\right), 6-8 . \mathrm{VII} .2010$, K. Tomkovich (1 9 , ZMUM); Mukhino $\left(60.89^{\circ} \mathrm{N} 68.70^{\circ} \mathrm{E}\right), 7-13$. VIII.2010, K. Tomkovich $\left(2 \mathrm{O}^{7} \mathrm{O}^{7}, 1\right.$, ZMUM); It'yakh River (61.85 $\left.\mathrm{N} 69.06^{\circ} \mathrm{E}\right)$, 22.VII.2010, K. Tomkovich $\left(2 \bigcirc^{7} \sigma^{7}, 2\right.$ + + ,, $\left.\mathrm{ZMUM}\right)$; Shapsha env. $\left(61.085^{\circ} \mathrm{N} 69.458^{\circ} \mathrm{E}\right), 1-$ 4.VIII.2010, K. Tomkovich (1 $\bigcirc^{7}, 1$ \%, ZMUM); $90 \mathrm{~km} \mathrm{SW}$ of Samburg (ca. $\left.66.4996^{\circ} \mathrm{N} 76.6467^{\circ} \mathrm{E}\right), 7 . \mathrm{VIII} .1976$, Gorodkov (1 + , ZISP); Labytnangi env. (66.6611 $\left.\mathrm{N} 66.3945^{\circ} \mathrm{E}\right)$, VII.1971, Ol'shvang (2 $\mathrm{O}^{\prime} \mathrm{O}^{7}, 1$ +, ZISP); Neroyka (ca. $\left.64.57^{\circ} \mathrm{N} 59.67^{\circ} \mathrm{E}\right)$, 30.VII.7.VIII.1988, 6.IX.1990, Malozemov (7 $0^{7} \sigma^{\top}, 4$ 우, ZISP); TarkoSale $\left(64.9144^{\circ} \mathrm{N} 77.7664^{\circ} \mathrm{E}\right), 1 . I X .1982$, Gorodkov $\left(20^{\top} \mathrm{O}^{\mathrm{T}}\right.$, ZISP); Volgograd Oblast: $\left(59.000^{\circ} \mathrm{N} 43.235^{\circ} \mathrm{E}\right), 7$. VI.2012, N. Vikhrev (1 $\sigma^{7}$, ZMUM); Kalach-na-Donu env. (48.65ำ $\left.43.60^{\circ} \mathrm{E}\right), 30 . \mathrm{IV} .2013$, N. Vikhrev (2 $0^{7} \sigma^{7}$, ZMUM); Dubovka $\left(49.0567^{\circ} \mathrm{N} 44.8249^{\circ} \mathrm{E}\right)$, 4.VII.2005, Nartshuk (1 9 , ZISP); Serafimovich $\left(49.5779^{\circ} \mathrm{N}\right.$ $42.7303^{\circ} \mathrm{E}$ ), 4.VIII.2011, Astakhov (1 $\sigma^{7}$, ZISP); Vorohezh (ca. $\left.51.601^{\circ} \mathrm{N} 39.1815^{\circ} \mathrm{E}\right), 1 . I X .1965$, Negrobov (1 + , ZISP); Yakutia: $20 \mathrm{~km}$ above of the mouth of the Biryuk River $\left(60.434^{\circ} \mathrm{N} 119.497^{\circ} \mathrm{E}\right)$, 15.VII. 2008, A. Ovchinnikov (4 O $^{7} 0^{7}$, ZISP); $9 \mathrm{~km} \mathrm{~W}$ of Zyryanka $\left(65.728^{\circ} \mathrm{N} 150.6356^{\circ} \mathrm{E}\right), 10 . \mathrm{VIII} .1974$, Gorodkov (5 $\mathrm{O}^{7} \mathrm{O}^{7}, 4$ 우, ZISP); Abaga $\left(61.0496^{\circ} \mathrm{N} 132.2808^{\circ} \mathrm{E}\right)$, 19.VII. 2008, A. Ovchinnikov (5 $0^{\top} \mathrm{O}^{\top}, 4$ 우, ZISP); airport Saskylakh $\left(71.9345^{\circ} \mathrm{N} 114.083^{\circ} \mathrm{E}\right)$, 24.VII.1988, Gorodkov (1 q, ZISP); Pokrovsk $\left(61.4672^{\circ} \mathrm{N}\right.$ $\left.129.1011^{\circ} \mathrm{E}\right), 21 . \mathrm{VII} .1986$, Makarkin (4 $\mathrm{O}^{7} \sigma^{7}, 1$ 1 , ZMUM); Balagannakh $\left(64.4956^{\circ} \mathrm{N} 143.817^{\circ} \mathrm{E}\right), 24$.VIII.1974, Gorodkov (1 $0^{7}$, ZISP); Batagay $\left(67.6539^{\circ} \mathrm{N} 134.6352^{\circ} \mathrm{E}\right)$, 9.VIII.1972, Gorodkov (4 $\mathrm{O}^{7} \mathrm{O}^{7}$, ZISP); Biryuk River, $4 \mathrm{~km}$ below the mouth of the Melichan River (ca. $60.4349^{\circ} \mathrm{N} 119.4955^{\circ} \mathrm{E}$ ), 13-14.VII.2008, A. Ovchinni$\operatorname{kov}\left(14{O^{7} O^{7}, 4}^{\circ}+{ }^{\circ}, Z I S P\right)$ Chai-Tumus Vill. $\left(72.3166^{\circ} \mathrm{N} 125.7333^{\circ} \mathrm{E}\right)$,
27.VII.1957, Gorodkov (2 우, ZISP); Chekurovka $\left(71.0469^{\circ} \mathrm{N}\right.$

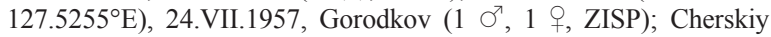
$\left(68.7503241^{\circ} \mathrm{N} 161.3321686^{\circ} \mathrm{E}\right), 18$.VIII.1971, 6.VIII.1972, Gorodkov (23 $0^{7} \sigma^{7}, 7$ 우, ZISP); Chokurdakh $\left(70.6187^{\circ} \mathrm{N} 147.8958^{\circ} \mathrm{E}\right)$,

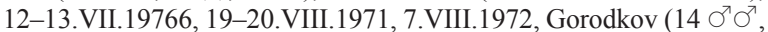
6 우, ZISP); Ebelyakh, Anabar $\left(70.8849^{\circ} \mathrm{N} 113.5704^{\circ} \mathrm{E}\right), 23$.VII. and 11.VIII.1988, Gorodkov (3 우, ZISP); Kular $\left(70.5737^{\circ} \mathrm{N}\right.$ $\left.134.2718^{\circ} \mathrm{E}\right)$, 3.VIII.1974, Gorodkov (5 $0^{7} \sigma^{7}, 1$ ㅇ, ZISP); Kyusyur $\left(70.6874^{\circ} \mathrm{N} 127.366^{\circ} \mathrm{E}\right), 14$ and 21.VII.1957, Gorodkov (2 $\mathrm{O}^{7} \mathrm{O}^{7}$, ZISP); Lena River, $7 \mathrm{~km}$ E of Olekminsk (ca. $60.3707^{\circ} \mathrm{N} 120.4362^{\circ} \mathrm{E}$ ), 31.VII.-2.VIII.1974, Nartshuk (5 O$^{7} \sigma^{7}, 3$ 우, ZISP); Mikhaylovka, $60 \mathrm{~km} \mathrm{NE}$ of Amga $\left(61.214^{\circ} \mathrm{N} 132.6815^{\circ} \mathrm{E}\right), 30$.VI. and 20.VII.1986, 7.VII. and 17.VIII.1987, Bagachanova (19 $0^{7} \sigma^{7}, 17$ 오, ZISP); same place, 13.VII., 12-15.VIII.1984, Averenskiy (4 +o+, ZISP); same place, 23.VII.19854, Sivtsev (2 O $^{7} \mathrm{O}^{7}$, ZISP); Mirnyy $\left(62.5401^{\circ} \mathrm{N}\right.$ $\left.113.9625^{\circ} \mathrm{E}\right)$, 23.VIII.1988, Gorodkov (1 $\mathrm{O}^{\top}$, ZISP); Neryuktyayinsk$1\left(60.2583^{\circ} \mathrm{N} 119.6732^{\circ} \mathrm{E}\right), 11$.VII. 2008, A. Ovchinnikov $\left(20^{7} \sigma^{7}, 1\right.$ +, ZISP); Nizhneyansk $\left(71.441^{\circ} \mathrm{N} 136.1355^{\circ} \mathrm{E}\right), 31$.VII.1974, Gorodkov ( $1 \mathrm{O}^{7}$, ZISP); Oktemtsy env. (ca. $61.67^{\circ} \mathrm{N} 129.42^{\circ} \mathrm{E}$ ), 6.VII. 2008, A. Ovchinnikov (4 $\odot^{7} \odot^{7}, 5$ 우, ZISP); Pokhodsk $\left(69.079^{\circ} \mathrm{N}\right.$ $\left.160.9615^{\circ} \mathrm{E}\right), 18$.VII.1973, Vinokurov (1 $\bigcirc^{7}, 1$ ㅇ, ZISP); Saskylakh env. ( $\left.71.9665^{\circ} \mathrm{N} 114.0949^{\circ} \mathrm{E}\right), 24 . \mathrm{VII} .1988$, Gorodkov $\left(1 \mathrm{O}^{7}, 2\right.$ 우, ZISP); Srednekolymsk $\left(67.4603^{\circ} \mathrm{N} 153.7104^{\circ} \mathrm{E}\right), 16$. VIII.1974, Gorodkov ( $2 \bigcirc^{7} \sigma^{7}$, ZISP); Stolby env. (ca. $62.9984^{\circ} \mathrm{N} 129.5319^{\circ} \mathrm{E}$ ), 26.VII. 2008, A. Ovchinnikov (14 $\mathrm{O}^{7} \mathrm{O}^{\top}, 12$ 우, ZISP); Teplyy Klyuch $\left(62.7836^{\circ} \mathrm{N} 136.8096^{\circ} \mathrm{E}\right)$, 20.VIII.1974, Gorodkov (1 9 , ZISP); Tiksi env. $\left(71.6351^{\circ} \mathrm{N} 128.8579^{\circ} \mathrm{E}\right), 9 . \mathrm{VII}$. and 10.VIII.1957, Gorod$\operatorname{kov}\left(1 \mathrm{O}^{7}, 1\right.$ ㅇ, ZISP); Tit Ary $\left(61.2281^{\circ} \mathrm{N} 127.7407^{\circ} \mathrm{E}\right), 29$. VII.1957, Gorodkov $\left(2 \bigcirc^{7} \sigma^{7}, 1\right.$, , ZISP); Tommot $\left(58.9634^{\circ} \mathrm{N} 126.2823^{\circ} \mathrm{E}\right)$, 31.VIII.1974, Gorodkov (6 $\mathrm{O}^{7} \mathrm{O}^{7}, 1$ 9 , ZISP); Ust'-Kuyga $\left(70.0007^{\circ} \mathrm{N}\right.$ $\left.135.5623^{\circ} \mathrm{E}\right), 27-28 . \mathrm{VII} .1974$, Gorodkov (5 $\sigma^{\top} \mathrm{O}^{\top}, 2$ 우, ZISP); 
Verkhoyansk $\left(67.5483^{\circ} \mathrm{N} 133.3961^{\circ} \mathrm{E}\right), 22 . \mathrm{VII}$. and 11.VIII.1974,

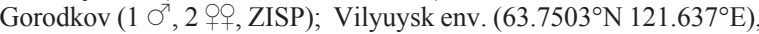
25.VIII.1988, Gorodkov ( $2 \sigma^{\top} \sigma^{7}, 3$ 90 , ZISP); Yakutsk env., ChochurMuran $\left(62.0345^{\circ} \mathrm{N} 129.6184^{\circ} \mathrm{E}\right), 15 . \mathrm{VIII} .1972$, Gorodkov (3 $\sigma^{7} \sigma^{7}, 1$ +, ZISP); same place, 1.VII.1974, Nartshuk (1 $\sigma^{7}$, ZISP); same place, 2.VII.2008, A. Ovchinnikov (2 $\sigma^{7} \sigma^{7}, 3$ OO , ZISP); Yakutsk env., Zhatay $\left(62.1597^{\circ} \mathrm{N} 129.8226^{\circ} \mathrm{E}\right), 16$. VIII.1972, Gorodkov $\left(2 \mathrm{O}^{7} \mathrm{O}^{7}, 2\right.$ 只, ZISP); Zhigansk $\left(66.7665^{\circ} \mathrm{N} 123.3721^{\circ} \mathrm{E}\right), 7$ and $15 . \mathrm{VIII} .1973$, Gorodkov (13 $\mathrm{O}^{7} \mathrm{O}^{7}, 5$ 우, ZISP); same place, 8.VI.1928, Nikiforov (1 †, ZISP); same place, 22.VI.1875, Chekanovskiy (1 + , ZISP); Yaroslavl' Oblast: Berditsyno (57.4558 $\left.{ }^{\circ} \mathrm{N} 40.1076^{\circ} \mathrm{E}\right), 3$. VII.1907, A. Yakovlev (1 $\sigma^{7}$, ZISP); Zabaikalsky Krai: Darasun env. $\left(51.2005^{\circ} \mathrm{N} 113.7024^{\circ} \mathrm{E}\right), 26 . V I .-7 . V I I .1949$, N. Filippov $\left(6 \sigma^{\top} \sigma^{\top}, 1\right.$ 9 , ZMUM); the upper reaches of the Uda River $\left(52.3878^{\circ} \mathrm{N}\right.$ 111.3680 ${ }^{\circ}$ ), 22.VI.2010, A. Medvedev (1 $\sigma^{7}$, ZMUM); Nerchinsk env. (ca. $\left.51.9807^{\circ} \mathrm{N} 116.5843^{\circ} \mathrm{E}\right), 17 . \mathrm{VI} .1912$, Dolf (2 $\sigma^{\top} \sigma^{\top}, 1$, ZISP).

DESCRIPTION. Male (Fig. 2), female. Mediumsized flies (3.2-4.8 $\mathrm{mm}$ long).

Head. Frontal vitta and fronto-orbital plate blackish in upper half and yellow in lower half. Face, parafacial and gena yellow. Postgena black, greyish dusted. Postcranium black, greyish dusted, covered with black setae in upper third and pale hairs in lower part. 3 orbitals, 2-4 frontals, 1 ocellar, 1 postocellar (very small), 1 inner vertical, 1 outer vertical; 2 pairs of vibrissae present. Antenna blackish in female (usually reddish inside apically) and yellow in male. Postpedicel with acute upper apical corner (Fig. 2), about 2.0 times as long as wide. Arista black, basally thickened, bare. Clypeus and proboscis black. Palpus yellow.

Thorax black, greyish dusted. Acrostical hairs in two rows, dorsocentrals $3+3$, including short erect seta on anterior margin of scutum, intra-alars $1+2$, supraalars $1+2$, postpronotals 2 , notopleurals 2 , postalars 2 . Proepisternum covered with hairs anteriorly, with 2 setae near lower margin. Proepimeron with one seta. Anepisternum covered with hairs in posterior half, with 3-4 setae along posterior margin. Katepisternum greyish dusted completely, covered with hairs in posterior half, with 1 strong seta in upper posterior corner and 1 moderate or small seta in upper anterior corner. Anepimeron bare. Scutellum black, greyish dusted, with a pair of basal scutellar and a pair of apical scutellar setae.

Legs. Fore coxa yellow, mid and hind coxae black. Fore trochanter yellow, mid and hind trochanters yellow or blackish. Femora, tibiae and tarsi of all legs yellow. Fore femur with a row of posterodorsal setae. Fore tibia with 1 dorsal and 1 posterior/posteroventral setae in lower half, with 1 preapical dorsal/posterodorsal, 0-1 preapical anterodorsal setae and 1 apical posterior seta. Mid femur with a row of anterior setae, with 1 preapical anterior/anterodorsal and 1 preapical posterodorsal setae. Mid tibia with 1 anterodorsal and 1 posterodorsal setae near middle, also with a ring of apicals in both sexes, additionally with 1 ventral seta near middle in female. Hind femur with rows of anterodorsal and anteroventral setae. Hind tibia with 2 anterodorsal, 2 posterodorsal, 1 preapical dorsal, 1 api$\mathrm{cal} /$ preapical anterodorsal and 1 apical anteroventral setae in both sexes, additionally with 1 anteroventral seta near middle in female.
Wing clear or yellowish tinged; veins brownish. $\mathrm{R}_{1}$ bare dorsally. Calypters, margins of calypters, and halteres yellowish.

Abdomen black, greyish dusted; female syntergite $1+2$ and tergites 3-6 with a row of marginal setae. Male sternite 4 transverse, oval (Fig. 12). Male sternite 5 with two median projections; lobes broad, narrowed apically and covered with many spinules dorsally (Fig. 18). Epandrium and surstyli as in Figs 24, 30.

DISTRIBUTION. Russia: Altai, Amur Oblast, Arkhangelsk Oblast, Astrakhan' Oblast, Bashkiria, Buryatia, Chelyabinsk Oblast, Chukotka, Irkutsk Oblast, Kaluga Oblast, Kamchatka Krai, Karelia, Kemerov Oblast, Khabarovsk Krai, Khakassia, Komi, Krasnoyarsk Krai, Kursk Oblast, Leningrad Oblast, Magadan Oblast, Moscow and Moscow Oblast, Murmansk Oblast, Nizhegorod Oblast, Novosibirsk Oblast, Omsk Oblast, Orenburg Oblast, Perm' Oblast, Primorsky Krai, Ryazan' Oblast, Sakhalin Oblast, Samara Oblast, Sverdlovsk Oblast, Tatarstan, Tomsk Oblast, Tuva, Tver' Oblast, Tyumen' Oblast, Volgograd Oblast, Vorohezh, Yakutia, Yaroslavl' Oblast, Zabaikalsky Krai. - Europe (widespread), Mongolia, North America (Alaska to Labrador).

Key to the SPECIES of TrichopaLPUS RondANi of Russia

1. Fore coxa yellow. Katepisternum with 1 strong seta in upper posterior corner and 1 moderate or small seta in upper anterior corner. Male sternite 4 and 5, epandrium, cerci and surstyli as in Figs 12, 18, 24, 30

\section{T. punctipes (Meigen)}

- Fore coxa black. Katepisternum with 1 strong seta in upper posterior corner only

2. Femora of legs yellow completely .. 2

Femora of legs black completely

3. Palpus yellow completely. Postpedicel reddish inside at base. Face black (yellow as exception). Male sternite 4 and 5, epandrium, cerci and surstyli as in Figs 7, 13, 19, 25 T. fraternus (Meigen)

- Palpus yellow in apical part and black basally, sometimes blackish completely. Postpedicel black completely. Face yellow. Male sternite 4 and 5, epandrium, cerci and surstyli as in Figs 10, 16, 22, 28

T. nigribasis (Curran)

4. Katepisternum greyish dusted completely ...................... 5

- Katepisternum with shining spot anteriorly ..................... 6

5. Femora of legs always black completely. Postpedicel black completely. Face white or yellowish. Male sternite 4 and 5, epandrium, cerci and surstyli as in Figs 11, 17, 23, 29 T. obscurellus (Zetterstedt)

- Femora of legs usually black in central part and yellow apically and basally, rarely blackish completely. Postpedicel reddish inside at base. Face black (yellow as exception). Male sternite 4 and 5, epandrium, cerci and surstyli as in Figs 7, 13, 19, 25

T. fraternus (Meigen)

6. Fore tibia with one strong posterior seta. Male sternite 4 and 5, epandrium, cerci and surstyli as in Figs 9, 15, 21, 27

T. nearcticus (Vockeroth)

- Fore tibia without strong posterior seta. Male sternite 4 and 5, epandrium, cerci and surstyli as in Figs 8, 14, 20,

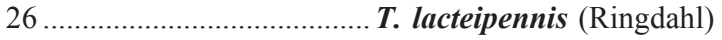


Acknowledgements. The work was conducted within the state project No AAAA-A16-116021660077-3. I am very grateful to Dr. Olga Ovchinnikova (ZISP) and Mrs. Galina Suleymanova (ZISP) for the loan of the material of Scathophagidae for study. I am also thankful to Dmitry Gavryushin (Moscow) for the photos of adults of T. fraternus and T. punctipes.

\section{References}

Bagachanova A.K., OvchinnikovA.N., Ozerov A.L. 2016. On the Fauna of Scathophagidae (Diptera) of Yakutia // Entomological Review. Vol.96. No.6. P.775-785.

Becker T. 1894. Dipterologische Studien. I. Scatomyzidae // Berliner Entomologische Zeitschrift. Bd.39. H.1. S.77-196.

Coquillett D.M. 1898. On the Dipterous family Scatophagidae // Journal of the New York Entomological Society. Vol.6. P.160165.

Curran C.H. 1927. Some new Canadian Scatophagidae (Diptera) // The Canadian Entomologist. Vol.59. No.11. P.253-261.

Cumming J.M., Wood D.M. 2009. Adult morphology and terminology // Brown et al. (eds.). Manual of Central American Diptera. Vol.1. Ottawa: National Research Council Press. P.9-50.

Engelmark R. 1999. Dungflies (Diptera: Scathophagidae) collected by the Swedish-Russian tundra ecology expedition '94, with the description of two new species; Nanna indotatum and Cochliarium sibiricum // Entomologisk Tidskrift. Arg.120. Häft 4. P.157-167.

Gorodkov K.B. 1970. [Family Scathophagidae (Cordyluridae, Scatomyzidae, Scopeumatidae)] // Bei-Bienko G.Ya. (ed.). Key to the insects of the European part of the USSR. Vol.V. Diptera Siphonaptera. Part 2. P.440-458 [in Russian].

Gorodkov K.B. 1986. Family Scathophagidae // Soós Á, Papp L. (eds.). Catalogue of Palaearctic Diptera. Vol. 11. Scathophagidae-Hypodermatidae. Akadémiai Kiadó, Buda-pest. P.1141 .

Hackman W. 1956. The Scatophagidae (Dipt.) of Eastern Fennoscandia // Societas pro Fauna et Flora Fennica. Fauna fennica II. Helsingforsiae. 67 pp.

Humala A.E., Polevoi A.V. 2009. On the Insect fauna of south-east Karelia // Trudi Karelskogo nauchnogo centra RAN. Vol.4. P.53-75.

Kahanpää J., Haarto A. 2014. Checklist of the families Scathophagidae, Fanniidae and Muscidae of Finland (Insecta, Diptera) // ZooKeys. Vol.441. P.347-367.

McAlpine J.F. 1981. Morphology and terminology-adults // McAlpine J.F., Peterson B.V., Shewell G.E, Teskey H.J., Vockeroth J.R., Wood D.M. (Coordinators). Manual of Nearctic Diptera. Vol.2. Ottawa: Research Branch. Agriculture Canada. Monograph 27. P.9-63.

Meigen J.W. 1826. Systematische Beschreibung der bekannten europäischen zweiflügeligen Insecten. Fünfter Theil. Hamm. $412 \mathrm{~S}$
Nelson J.M., Greve L. 2002. New species of dung flies (Diptera, Scathophagidae) from Norway with a checklist of the Norwegian Scathophagidae // Norwegian Journal of Entomology. Vol.49. P.41-47.

Ovchinnikov A.N. 2004. Data on the fauna of Scathophagidae (Diptera) of the Volga Region // Russian Entomological Journal. Vol.12. No.4(2003). P.421-423.

Ovchinnikov A.N. 2005. To the fauna of Scathophagidae (Diptera) in the Saratov and Orenburg Provinces. Chirov P.A., Anikin V.V. (eds.). Entomological and Parasitological Investigations in Volga Region. No.4. P.155-156.

Ovchinnikov A.N. 2013. [Dvukrylye semeistva Scathophagidae (Diptera) evropeiskoy chasti Rossii: vidovoi sostav, rasprostranenie i morfoadaptivnye preobrazovania yaitseklada]. PhD Thesis. St-Petersburg: Zoologicheskiy Institut RAN. 151 pp. [In Russian]

Ozerov A.L., Barkalov A.V. 2014. On the fauna of Scathophagidae (Diptera) of Taimyr Peninsular (Russia: Krasnoyarskiy Kray) // Euroasian Entomological Jornal. Vol.13. No.6. P.560-565.

Ozerov A.L., Krivosheina M.G. 2014. To the fauna of dung flies (Diptera: Scathophagidae ) of Russian Far East // Russian Entomological Journal. Vol.23. No.3. P.203-222.

Ringdahl O. 1920. Neue skandinavische Dipteren // Entomologisk Tidskrift. Vol.41. P.24-40.

Ringdahl O. 1936. Anteckningar till svenska arter av familjen Scopeumatidae (Diptera) // Entomologisk Tidskrift. Arg.57. Haft.2-3. S.158-179.

Rondani C. 1856. Dipterologiae Italicae Prodromus. Vol. I. Genera Italica ordinis dipterorum ordinatim disposita et distincta et in familias et stirpes aggregata. Parmae. $228 \mathrm{pp}$.

Rondani C. 1866. Scatophaginae Italicae collectae distinctae et in ordinem dispositae. Dipterolodiae Italicae Prodromus. Pars.VII. Fasc.I. Bernardoni, Milano. 52 pp.

Šifner F. 2008. A catalogue of the Scathophagidae (Diptera) of the Palaearctic region, with notes on their taxonomy and faunistics // Acta Entomologica Musei Nationalis Pragae. Vol.48. No.1. P.111-196.

Stuckenberg B.R. 1999. Antennal evolution in the Brachycera (Diptera), with a reassessment of terminology relating to the flagellum // Studia Dipterologica. Vol.6. S.33-48.

Vockeroth J.R. 1965. Subfamily Scatophaginae // Stone A, et al. (eds.). A catalog of the Diptera of America north of Mexico. United States Department of Agriculture. Agriculture Handbook. No.276. P.826-842.

Vockeroth J.R. 1987. 103. Scathophagidae // McAlpine J.F. et al. (eds). Manual of Nearctic Diptera. 2. Agriculture Canada, Research Branch, Ottawa, Monograph 28. P.1085-1097.

Vockeroth J.R. 1995. Validation of nomina nuda of Nearctic Tethinidae, Scathophagidae, and Muscidae proposed in Manual of Nearctic Diptera // Proceedings of the Entomological Society of Washington. Vol.93. No.3. P.732-734.

Zetterstedt J.W. 1846. Diptera Scandinaviae disposita et descripta. Tomus quintus. Ex officina lundbergiana, Lundae [= Lund]. P.1739-2162. 